\title{
Makedonci i Makedonija u Prvom svjetskom ratu Prilog istraživanju percepcije nacionalnih identiteta
}

\begin{abstract}
Balkanski ratovi bili su prijeloman trenutak u povijesti balkanskih naroda, osobito makedonskog. Masovno sudjelovanje Makedonaca pod zastavama susjednih država u nadi za oslobođenje od osmanske vlasti izjalovilo se jer je makedonski etnički teritorij, uz suglasnost velikih sila, podijeljen među susjednim državama, a to je stanje zacementirano Prvim svjetskim ratom. Rad se fokusira na sudjelovanje Makedonaca u Prvom svjetskom ratu, koje prešućuju i povjesničari i političari, koji i dalje vode politiku onog vremena, podržavajući time to što makedonsko ime, jezik i drugo negiraju susjedi nezadovoljni tadašnjim „rješenjem“ makedonskog pitanja. Povjesničari, zarobljeni u okviru nacionalnih ili, bolje rečeno, nacionalističkih historiografija, prešućivanje žrtava, kako vojnih, tako i civilnih, opravdavaju tobožnjom nacionalnom neosviještenošću Makedonaca, zanemarujući postojeća svjdočanstva o nacionalnoj svijesti. Pritom prešućuju propagande susjeda, koji su preko svojih crkava na makedonskom teritoriju vršili nasilnu asimilaciju, što je bilo potkrijepljeno terorom ubačenih oružanih četa. Rad se zasniva na objavljenoj arhivskoj građi, izvješćima stranih novinara te na svjedočanstvima sudionika u ovim ratovima, objavljenima nakon njihova završetka.
\end{abstract}

Ovaj se članak zasniva na izvornim dokumentima koji su dosada ostali neobrađeni kako bi povjesničarima ukazao da udio Makedonaca u I. svjetskom ratu nije dovoljno istražen, ali ujedno predstavlja i reakciju na slijepo nastavljanje prošlovjekovne politike prema Makedoniji u našoj suvremenosti. Razlog takve politike neistraženost je ovog pitanja kao i šutnja povjesničara. Ipak, treba kazati da su do 1945. povijest makedonskog naroda pisali drugi, u prvom redu susjedi, i da su tek nakon završetka II. svjetskog rata formiranjem makedonske države, znanstvenih i obrazovnih ustanova Makedonci dobili priliku istraživanja vlastite povijesti. Srpski, bugarski i grčki povjesničari donedavno su prešućivali sudjelovanje vojnika Makedonaca u Balkanskim ratovima, nazivajući ih srpskim, bugarskim ili grčkim vojnicima po imenu države koja ih je mobilizirala, a s ciljem opravdavanja podjele Makedonije. No, ništa se ne može vječno kriti i polako se počinju objavljivati činjenice. ${ }^{1}$ Iz dokumenata ne vidi se samo sudjelovanje

РАТКОВИЋ 1975: 455-456. 
Makedonaca u Velikom ratu, nego i njihov nacionalni identitet. Zato je jedan od imperativa za povjesničare, prije svega za makedonske, istraživanje tog razdoblja.

Ime Makedonije prešućivalo se, čak i zabranjivalo, već na početku 20. stoljeća. Sultan Abd-ul-Hamid izdao je 7. travnja 1903. naredbu (irade) da se u predstavkama i priopćenjima ne koristi domaće ime Makedonija (Sl. 1) . ${ }^{2}$ Zbog toga se u službenim ispravama sve do kraja osmanske vlasti koriste nazivi sandžaka rumelijskog beglerbegata (Solunski, Bitolski i Skopsko-kosovski sandžak). Ukaz je najvjerojatnije donesen pod pritiskom i na zahtjev Rusije i Austro-Ugarske jer bi ime moglo asocirati na novu političku formaciju na Balkanu. Naime, Rusija i Austro-Ugarska znale su da se u Makedoniji priprema ustanak. ${ }^{3}$ Išlo se toliko daleko da su osmanske vlasti tražile od predstavnika American Bible Societyja sa sjedištem u Solunu da se u prijevodu Prve poslanice apostola Pavla Solunjanima ime Makedonije ${ }^{4}$ zamijeni suvremenim nazivom Solunski vilajet. ${ }^{5}$

Ni u međunarodnim ugovorima balkanskih država nema imena Makedonije ni Makedonaca, iako su se one njime koristile u međusobnoj komunikaciji. ${ }^{6} \mathrm{Na}$ zemljovidima koji se prilažu međunarodnim ugovorima toponimi su makedonski. Takav je ugovor o prijateljstvu između Srbije i Bugarske, sklopljen 29. veljače 1912. s tajnim aneksom o podjeli teritorija između Šar-planine, Rodopa, Ohridskog jezera i Egejskog mora. ${ }^{7}$ Isto je i s ugovorom o savezništvu Kraljevina Srbije i Grčke, koji je sklopljen 19. svibnja 1913. u Solunu, gdje se koristi termin „europska Turska“ ${ }^{8}$ Iz razumljivih razloga nema imena Makedonije u bukureštanskom mirovnom ugovoru, kojim su je susjedi 1913. podijelili među sobom. ${ }^{9}$ Ime Makedonije, međutim, stoji na nadgrobnim spomenicima vojnika koji su pali za nju

2 Dokument se čuva u vladinoj Generalnoj upravi državnih arhiva, Tajništvu za osmanske poslove - Inspektorat za klasifikaciju rumelijskih dokumenata u Istambulu (Başsbakanlik Devlet Arşivleri Genel Müdürlügü, Osmanli Daire Bakanligi, Rumeli Müfettişligi Tasnifi, Sadaret ve Bakitabet Evraki). Prijevod na makedonski objavio je СТОЈАНОВСКИ 2006: 317.

3 Prethodno su 17. veljače 1902. Austro-Ugarska i Rusija potpisnicama Berlinskog kongresa sugerirale provođenje paketa reformi (,februarske“ ili „padarske“ reforme), koje bi u Makedoniji očuvale sultanski suverenitet te obnovile red i mir. Dana 3. veljače reforme su dostavljene Visokoj Porti, koja ih je prihvatila, ali one ne samo da se nisu u potpunosti provele, već su bile i bezuspješne jer nisu riješile bitan problem - autonomiju Makedonije. Ostale europske sile poslije Berlinskog kongresa 1878. nisu bile osobito zainteresirane za Balkan.

4 I Sol 1, 7 i 8; 4, 10. ,...sve u nevolji mnogoj prigrliše Riječ s radošću Duha Svetoga tako da postadoše uzorom svim vjernicima u Makedoniji i Ahaji.“; ,... a to doista i činite prema svojoj braći u cijeloj Makedoniji.“

5 Dokumente o tome objavio je njujorški časopis The Sun, 16. VI. 1903., u članku „Turk as the critic of the Bible". Vidi magazin Глобус, br. 101, 24. III. 2009., 28.

6 ХРИСТОВ И ДОНЕВ 1994: 162-166, 182-183.

7 СТОЈЧЕВ И СТОЈЧЕВ 2013: 446-450, karta br. 15 i 16.

8 Isto: $467-470$.

9 Isto: 563-671 (faksimil ugovora). 


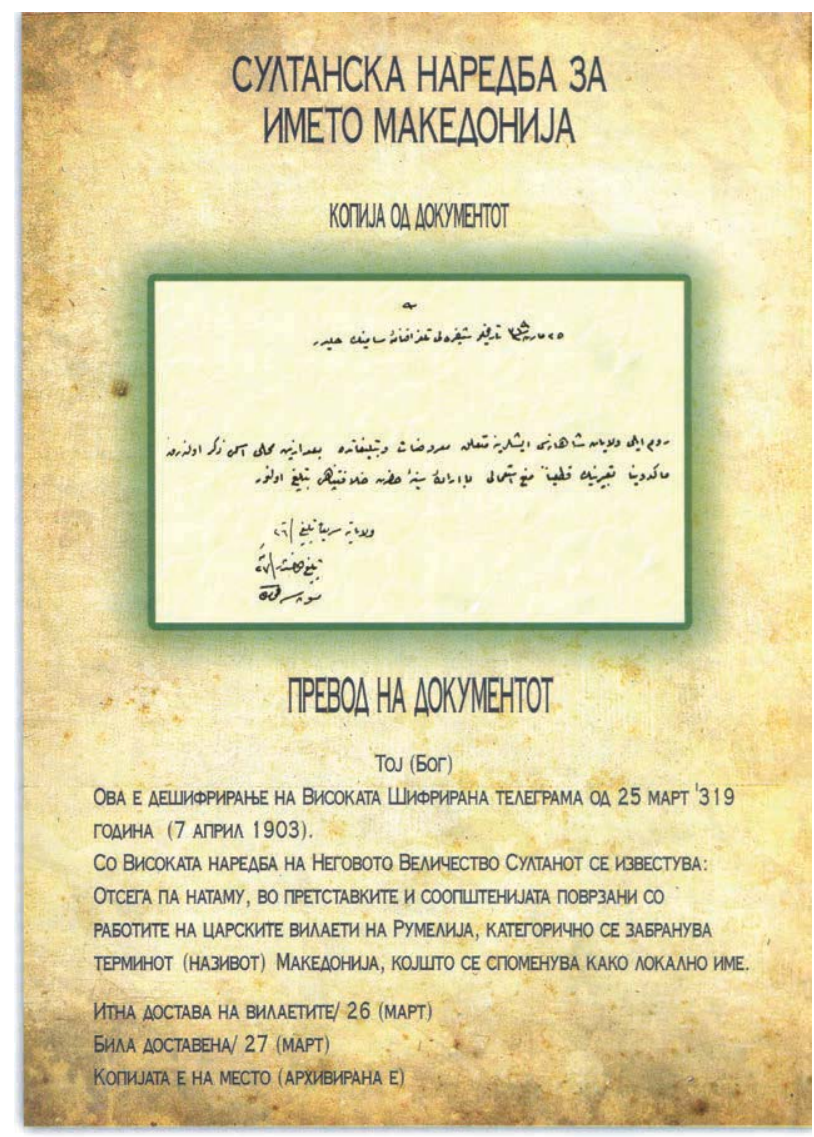

1. Zabrana korištenja imena Makedonija: naredba (irade) Abd-ul-Hamida II, НАЈДОВСКА И ПЕТРЕСКА 2008: 16.

(v. niže). Nakon podjele Makedonije njezino su ime zabranjivale grčke vlasti, a bugarske u manjoj mjeri. Ne samo što je ime Makedonije bilo strogo zabranjeno, već su u tzv. egejskom dijelu (danas Republika Grčka) zakonom od 21. studenog 1926. slavenska i turska osobna i mjesna imena bila zamijenjena grčkima. ${ }^{10} \mathrm{Kad}$ se završetkom hladnog rata promijenio odnos među velikim silama, grčko državno Ministarstvo za „sjevernu Grčku“ (Voreia Ellada) 1982. preimenovano je u Ministarstvo za Makedoniju i Trakiju, za koje je oduvijek bilo nadležno. I makedonski se jezik zabranjivao ${ }^{11}$, ne samo u prošlosti, već i danas, kako u kolijevci

\footnotetext{
DANFORTH 1995: III. pogl.; VAN BOESCHOTEN 1993.

11 Za svaku makedonsku riječ plaćala se novčana kazna, KARAKASIDOU 1997; Isti 2002. Vidi rješenje br. 134 od 13. XII. 1936., kojim se u Općini Asiros zabranuju svi idiomi, osim grčkoga, te zakletva seljana Krpešine (sada Atrapos) da neće govoriti slavenskim idiomom. Usp. Elliniki foni, 8. VIII. 1959.; Foni tis Kastorias, 4. X. 1959.
} 
europske demokracije - Republici Grčkoj - tako i u Republici Bugarskoj, dvjema članicama Europske unije. Grčka uopće ne priznaje da makedonska nacija postoji. Bugarska ne priznaje da na njezinome teritoriju ima Makedonaca, a makedonski jezik smatra dijalektom bugarskoga. ${ }^{12}$

Svima je jasan razlog zbog kojeg južni susjed (Republika Grčka) odbija i ne prihvaća ime Makedonije te sve njegove izvedenice (ime jezika, naroda itd.), no nijedan razuman čovjek ne može razumjeti podršku zapadnoeuropskih političara nerazumnom zahtijevanju da jedna zemlja promijeni svoje ime i svoj identitet. ${ }^{13}$ Stručnjaci za balkansku povijest uopće nisu iznenađeni ni začuđeni iracionalnim ponašanjem južnog susjeda Makedonije jer je to najbalkanskija od svih balkanskih zemalja, u negativnom smislu riječi koji nazivu „balkanski“ pridaju Europljani koji tu zemlju podržavaju. Naime, prema njima Balkan nije dio europske kulture. Da bi pokazali razliku između svoje, po njima visoke kulture, zapadni Europljani dali su pojmu „balkanski“" negativno značenje. ${ }^{14} \mathrm{~S}$ druge strane, vlastiti kulturni i politički kôd lociraju upravo na Balkanu, točnije u antičkoj Grčkoj - Heladi. Ovdje nema logike, kao što je nema ni u njihovu slijepom nastavljanju prošlovjekovne politike prema Makedoniji.

Zbog tragičnog ishoda Balkanskih ratova za makedonski narod (makedonski je povijesni prostor bio podijeljen između Grčke, Bugarske, Srbije, a uzak pojas uz zapadnu granicu Makedonije, oblasti Golo brdo i Gora, dodijeljen je Albaniji, dok se odcjepljenjem Kosova od Republike Srbije, kojoj je pripadao dio oblasti Gora, broj država povećao na pet ${ }^{15}$ ), koji je Prvim svjetskim ratom zacementiran, državne institucije Republike Makedonije obilježile su skromno, može se čak reći stidljivo, ove obljetnice. ${ }^{16}$ Više je nego sigurno da bi glasnije obilježavanje shvatili kao iredentizam, ne samo susjedi, već i zapadne države koje su sudjelovale u tim ratovima i ozakonile komadanje Makedonije te koje prešućuju makedonske žrtve, kako vojne, tako i civilne. Civilno je stanovništvo stradavalo od rekvizicija za vojske, bolesti, gladi. Ovome treba dodati teror srpskih, grčkih i bugarskih četa, koje su se ubacivale nakon podjele Makedonije,

12 Podrobnije o tome vidi ПРОЕВA 2010: 188-195.

13 O uzrocima ovakvog gledišta „Stare dame“ Europe podrobno vidi ПРОЕВA 2012: 148-155, o europskoj mitomaniji.

14 2012. znanstveni skup „Сто години од балканските војни“, bez ijednog stranog istraživača; zajednički jednodnevni makedonski skup МАНУ i Instituta za nacionalnu istoriju (ИНИ) „Македонија и Македонците во првата светска војна“ održan je u Skopju 11. prosinca 2014. O balkanskim ratovima vidi i PETTIFER I BUCHANAN 2015: 92-110. 
kao i asimilaciju, te zato nitko razuman ne može vjerovati u teorije da su se susjedi borili za njezino oslobođenje. Nije stoga čudno što su ljudi priželjkivali povratak Turaka. ${ }^{17} \mathrm{I}$ u tome je korijen problema Grčke s imenom Republike Makedonije. Više je nego jasno da nije riječ o imenu, već o makedonskom pitanju, koje je u Balkanskim ratovima ,riješeno“ parcijalno i subjektivno, što u Prvome svjetskom ratu nije ispravljeno. To je shvatilo i u svoje izvješće uključilo Carnegijevo povjerenstvo: ,...budući da su Bukureštanskim ugovorom sankcionirani nezakoniti zahtjevi pobjedničkih naroda, on je djelo nepravde koje vrlo vjerojatno neće moći odoljeti djelovanju vremena. Ne bi li bilo više u skladu s istinskim osjećajem solidarnosti među narodima prepraviti ugovor, nego čekati da se razvije i sazrije njegov loši plod?" ${ }^{18}$ To pokazuje da je problematiziranje makedonskog imena i identiteta rezultat politike velikih sila iz vremena Balkanskih ratova, koja se, nažalost, nastavlja i danas, jer nema ni volje ni hrabrosti - a još manje poštenja - za priznanje kako je ona bila pogrešna, iako su to članovi Carnegijeva povjerenstva priznali odmah poslije rata. ${ }^{19}$ Francuski senator, barun d'Estournelles Constant napisao je: „Ondje postavljene demarkacijske linije nisu ni izdaleka prirodne niti u suglasnosti s nacionalnim tendencijama naroda. Treći Bukureštanski ugovor posijao je novo sjeme razdora povrijedivši osjećaj nacionalnosti: podijelio je balkanske narode po istom načelu kao Bečki ugovor

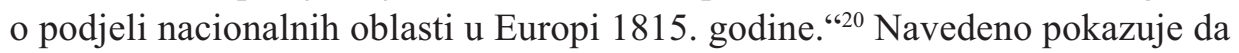
političari nisu sposobni ništa naučiti iz povijesti.

Izbjegavaju li političari na svaki način makedonsko ime, potrebno je, u najmanju ruku, osobito dok se pokušavaju baviti znanošću, neispravljanje dokumenata i neiskrivljavanje činjenica. U nizu primjera ovakvog ponašanja ističe se izložba o stotoj obljetnici početka I. svjetskog rata u organizaciji francuske ambasade u Skopju. Ime jedne od četiriju velikih bojišnica, makedonske, nazvane i solunskom i južnom bojišnicom, zaobilazi se na svim događanjima u vezi s obilježavanjem godišnjice te se preinačuje u istočnu bojišnicu (Sl. 2).

17 KЕНАН 2000: 314.

„... бидејќи Букурешкиот договор ги санкционирал илегитимните барања на победничките начионалности, тој е дело на неправда кое по секоја веројатност не ке може да му се спротивстави на дејството на времето. Зар не би било повеке во согласност со виситнското чувство на солидарност на народите да се преправи договорот одошто да се чека да се развива и да зрее неговиот лош плод?““. КЕНАН 2000: 245.

19 КЕНАН 2000: 50, „Поделена Европа и нејзиното деморализирачко дејство на Балканот.“ Objektivnu analizu francuskog stajališta daje ГЕЛТОН 2003: 29-40.

20 ,Демаркационите линии поставени таму ни оддалеку не се природни или во согласност со националните тенденции на народите. Третиот договор од Букурешт посеа ново семе на раздор со повреда на чуството на начионалноста: тој ги подели блаканските народи врз принципот врз кој договорот од Виена ги делеше начионалните области во Европа во 1815.“КЕНАH 2000: 193. 


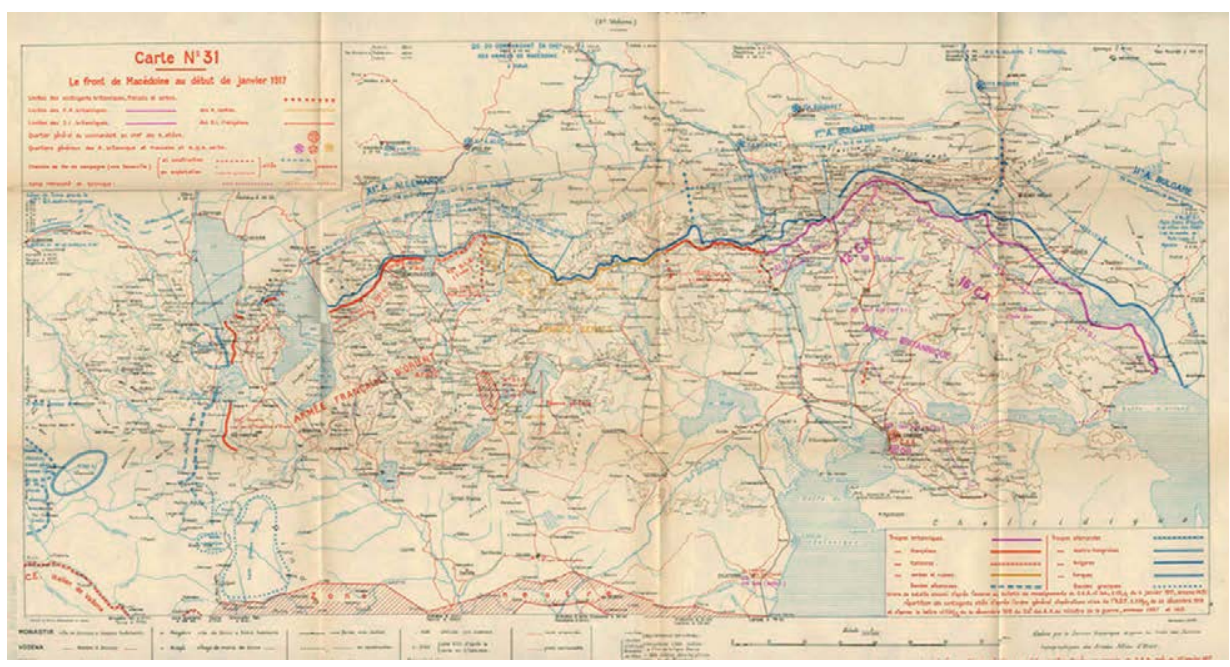

2. Makedonski front-karta.

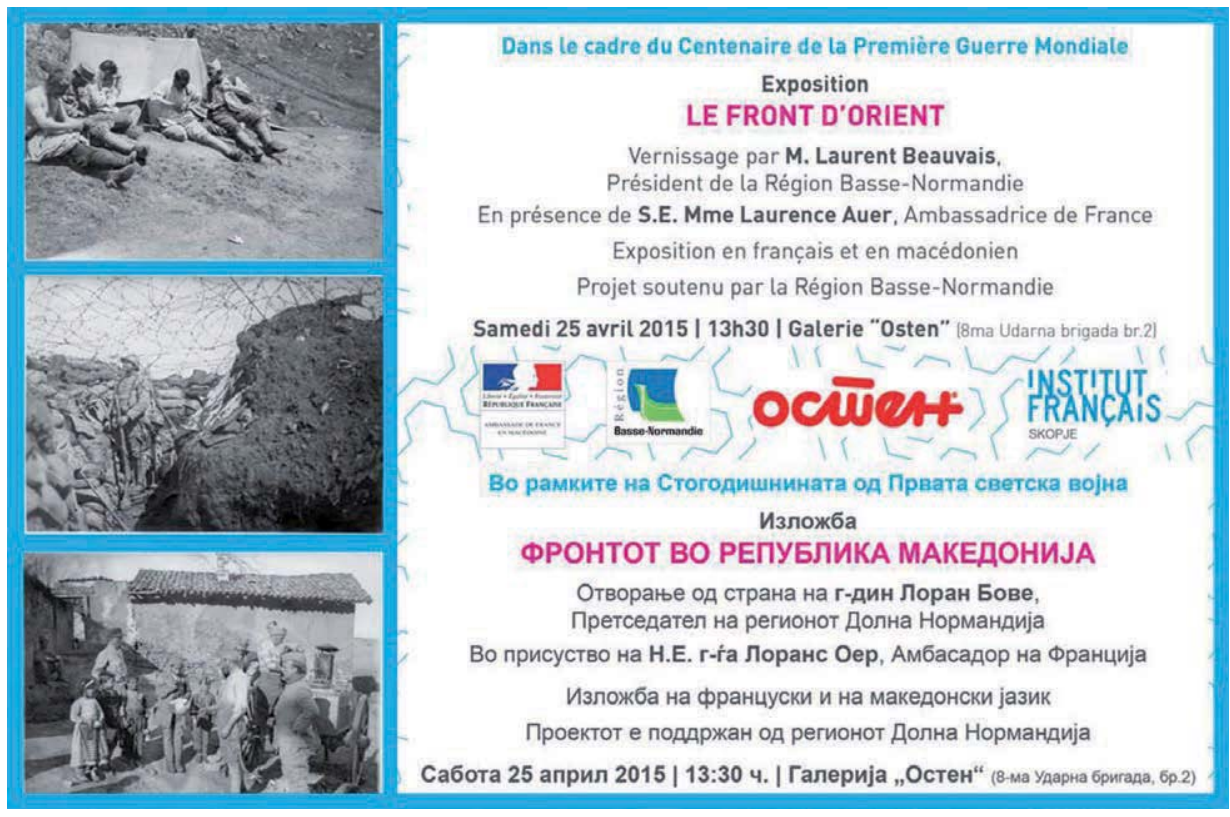

3. Plakat izložbe Le front d'Orient-Skopje, 25. IV. 2015. 
Plakat ${ }^{21}$ i svi panoi na izložbi dvojezični su, francuski i makedonski. Prva dva reda plakata identična su na obama jezicima, ali u trećem i najvažnijem retku s naslovom izložbe pojavljuje se golema razlika (Sl. 3). ${ }^{22}$ Iz naslovâ Exposition sur le Front d'Orient і Фронтот во Република Македонија proizlazi da su postavljene dvije različite izložbe. ${ }^{23}$ Brošure koje je francuska ambasada objavila na makedonskom, albanskom i francuskom jeziku također imaju različite naslove, iako im je sadržaj posve isti. ${ }^{24} \mathrm{Na}$ četvrtoj stranici brošure, u prvome odjeljku koji je naslovljen Источен фронт наречен и Македонски, Солунски фронт или Јужен фронт uočava se da je istočna bojišnica bila jedna od četiriju velikih bojišnica na europskome kontinentu, koji su sačinjavale baltičke zemlje, Rusija, Rumunjska i Bugarska „(еден од четирите големи фронтови на европскиот континент..... на исток (Балтичките земји, Русија, Романија и Бугарија).“ Drugim riječima, stvarna istočna bojišnica, prema vlastitom svjedočenju autora, nije obuhvaćala Makedoniju. U drugom pak odjeljku piše da je istočna bojišnica prolazila kroz četiri zemlje, Grčku, Bugarsku, tadašnju Srbiju (u čijem je sastavu

${ }_{21}$ Na plakatu izložbe najprije stoji logotip francuske ambasade, zatim pokrajine Donje Normandije, ime Galerije Osten, gdje je izložba bila postavljena, te na kraju logotip Francuskog instituta u Skopju. Na dnu plakata, ispred datuma (25. travnja 2015.) i mjesta izložbe (Skopje), piše da je projekt podržala regija Donja Normandija.

22 U francuskoj ambasadi i u Francuskom institutu ima vrhunskih prevoditelja, znalaca obaju jezika, francuskog i makedonskog; jasno je da u pitanju nije pogrešan prijevod. Na moje pitanje tko je autor izložbe nitko nije imao odgovor. To jasno pokazuje da su organizator i tajanstveni autor ili autori izložaba (s obzirom na dva naslova, može biti više autora) svjesni iskrivljavanja činjenica o događaju koji obilježavaju. Najprije mi je rečeno da je to Ambasada. Kad sam ukazala na to da Ambasada, kao ustanova, može biti organizator, ali nikako autor, rečeno mi je da je autor izložbe neko povjerenstvo. Iako sam inzistirala, nije mi bilo kazano ni ime njegove čelne osobe, ni nekog njegova člana. Ravnateljica Francuskog instituta, Isabelle Marchi Barbaux, poručila mi je da svoje primjedbe napišem u knjigu dojmova. Kad sam rekla da ne mogu pisati na licu mjesta, predložila mi je neka svoje primjedbe pošaljem Ambasadi, ponovno bez imena nadležne osobe. Na to sam demonstrativno otišla s izložbe. Zbog ovakvog odnosa odlučila sam svoje primjedbe objaviti u članku, kao putokaz našim šutljivim povjesničarima. Nema potrebe opominjati političare. Na njihovu smo šutljivost i konformizam odavno naviknuli, što nije prisutno samo kod naših, već u manjoj ili većoj mjeri kod svih političara. Nakon punih jedanaest dana, post festum, od g. Branka Čobanova, kulturnog atašea Republike Francuske i zamjenika ravnatelja Francuskog instituta u Skopju, dobila sam ime odgovornog - Lt. Col. Stéphane Loechleiter, Defence Attaché - kojemu sam e-poštom poslala svoje primjedbe u pet točaka.

23 To je neshvatljivo za zemlju s dugom muzeološkom tradicijom poput Francuske, čiji je prepoznatljivi simbol jedan od najstarijih i najčuvenijih muzeja na svijetu, Musée du Louvre, otvoren 10. kolovoza 1793.

24 Centenaire de la Première Guerre Mondiale, Le front d'Orient 1914-1918, Skopje 2014. Dostupno i na stranici Francuske ambasade u Skopju (http://wwwambafrance-mk.org/-Brochurefront-d-Orient). Brošura na makedonskom jeziku naslovljena je 100 години Прва светска војна, Фронтот и местата на сеќавање во Република Македонија. Brošura na albanskom ima isti naslov kao makedonska. 
bio i teritorij današnje Republike Makedonije) i Albaniju (...низ четири земји: Гриија, Бугарија, тогашна Србија во чиј состав беше и територијата на денешна Република Македонија и Албанија), što je u protuslovlju s onim što je rečeno u prvom odjeljku. Ako je Srbija izostavljena pri nabrajanju zemalja istočne bojišnice, niti Makedonija - koja je tada bila u njezinu sklopu - nije dio istočne bojišnice. Svatko tko je pročitao da su istočnu bojišnicu tvorile baltičke zemlje, Rusija, Rumunjska i Bugarska zapitat će se kako je moguće da je makedonska, solunska ili južna bojišnica istočna, osobito zato što niže na istoj stranici piše kako je Makedonija pripadala jugozapadnom Balkanu. To znači da ni Makedonija ni makedonska bojišnica nisu na istoku.

Ovdje treba ukazati na činjenicu da se u izvorima toga doba nazivom istočna vojska obuhvaćaju i vojske balkanskih zemalja, kako bi se razlučile od francuske vojske, koja se borila na Zapadu, u Francuskoj i Belgiji. Za razliku od termina za vojske, termini za bojišnice mnogo su precizniji iz razumljivih vojnih, operativnih razloga. Točno se zna, osim ako se ne želi znati, koja se bojišnica gdje nalazila i kako se zvala. Ovdje se u biti radi o jezičnoj zbrci u prijevodu; naime, $\mathrm{u}$ francuskom se jeziku koriste dva termina. Prvi je front de l'est ili front oriental, doslovno istočna bojišnica, a odnosi se na baltičke zemlje, Rusiju, Rumunjsku i Bugarsku. Drugi je Front d'Orient, što se također prevodi kao istočna bojišnica, ali se odnosi isključivo na Malu Aziju i piše se velikim slovom. Tako se i na našim fakultetima predmet u sklopu kojega se proučavaju civilizacije Male Azije, Mezopotamije i Egipta zove Povijest starog Istoka. Termin se u francuskom jeziku koristi i za tijek I. svjetskog rata te bi ga trebalo prevoditi kao bojišnicu na Istoku, a ne istočnu bojišnicu. ${ }^{25}$

Da bi se izbjegnula ovakva jezična nepreciznost i zbrka (bojišnica na Istoku i istočna bojišnica), za Front d'Orient u balkanskoj se historiografiji koristi termin južna bojišnica, kojim su se jedanput poslužili čak i autori brošure (naslov odjeljka na str. 4), ali ga nisu prihvatili i nisu se njime sustavno koristili. ${ }^{26} \mathrm{Na}$ ovakvo preimenovanje makedonske bojišnice ukazao je Aleksandar Stojčev, doktor povijesnih znanosti i stručnjak za razdoblje, na zajedničkom predavanju s pukovnikom

25 Lijep primjer da se ne može uvijek prevoditi doslovce jest termin Macédoine serbe u brošuri na francuskom jeziku, što je u makedonskoj brošuri prevedeno kao „vardarski dio Makedonije“ (вардарски дел на Македонија, str. 3, 7, 8) ili pak kao „srpski dio Makedonije“ (српски дел на Македонија, str. 18) jer bi doslovan prijevod „srpska Makedonija“ implicirao srpsku pripadnost stanovništva.

26 Nekompetentnost autora vidi se i prema drugim greškama. Bugarska se na istoj stranici (4) jedanput ubraja u istočnu bojišnicu (front de l'est), a drugi put u Bojišnicu na Istoku (Front d'Orient); Mariovska visoravan nazvana je planinom na str. 8, a masivom (valjda planinskim) na str. 12; na karti na str. 9 izmišljena je bojišnica u Albaniji - linija makedonske bojišnice produžena je do Jadranskog mora, iako ondje nije bilo stvarne bojne linije; svugdje se koristi ime današnje države „Turska“, umjesto ondašnjega „Osmansko Carstvo“. 
Maxom Schiavonom pod naslovom Savezničke vojske na Istoku: od poraza na Dardanelima do konačne pobjede (1915 - 1918). ${ }^{27}$ Iako njegova primjedba nije bila pobijena, makedonsko se ime bojišnice nastavlja izbjegavati, kako se vidi iz izložbe gdje je makedonska, odnosno solunska bojišnica preimenovana u bojišnicu u Republici Makedoniji, koje tada nije bilo. Ako se htjelo naglasiti da se izložba odnosi samo na dio bojišnice koji je danas obuhvaćen Republikom Makedonijom, na panoima se nije smio prikazati nijedan dokument ${ }^{28}$ i nijedna karta koja obuhvaća cijelu južnu, tj. solunsku bojišnicu, koja je danas u granicama Republike Grčke - jer bi Grčka to mogla shvatiti kao provokaciju i iredentizam Republike Francuske, inače njezina vjernog prijatelja i pobornika.

Isti je odnos i prema geografskim imenima u Republici Makedoniji. Naime, i na panoima i u brošuri toponimi su uglavnom navedeni u turskoj (što se može razumjeti, s obzirom na činjenicu da je turski do Balkanskih ratova bio službeni jezik) ili u grčkoj verziji; pri tome se ne navode izvorna slavenska imena kojima se koristilo domaće stanovništvo, a koja su danas službena u Republici Makedoniji. Naročito odskače primjer Skopja, za koje na panou s naslovom „Kronologija sukoba“" (Хронологија на судирот) na dnu, najsitnijim slovima, piše da je ime Ускуб ${ }^{29} 1912$. službeno promijenjeno u Скопле. To je argument više za korištenje dvama imenima, a ne samo turskoga, koje - osim u rijetkim slučajevima - stoji na svim panoima izložbe. Uz ovakvo prikazivanje događaja manje upućeni ne mogu shvatiti o kojoj se bojišnici i u kojoj zemlji radi. Primjerice, nitko iz mlađih generacija ne zna da je Monastir bilo ime Bitole, koje je u svojem makedonskom obliku ispisano samo jedanput na drugom panou slijeva $\mathrm{i}$ jedanput na str. $8 \mathrm{u}$ brošuri na makedonskom jeziku. U francuskoj brošuri figurira samo ime Monastir te će francuski čitatelji uzalud na karti tražiti grad kad se budu spremali posjetiti grobove svojih sunarodnjaka. ${ }^{30}$

$\mathrm{Na}$ istome je panou prikazan zemljovid sa stanjem bojišnice 16. prosinca 1916., na kojemu je izvorna legenda „Makedonska bojišnica 16. prosinca 1916“ (Le front de Macédoine le 16 decembre 1916). Njezin makedonski „prijevod“ glasi „Stožerni zemljovid bojišnice 16. prosinca“ (Штабна карта Фронтот на 16 декември)! Postavlja se pitanje ZAŠTO je promijenjena legenda originalnog dokumenta, što je krivotvorina, i s kojim se ciljem izbjegava ime Makedonije.

27 Сојузничките сили на Истокот: од поразот кај Дарданелите до крајната победа (1915 - 1918) / Les armées alliées en Orient: du desastre des Dardanelles à la victoire finale (1915 1918).

28 Na četvrtome panou zdesna nalazi se dokument o misi, koju je francuski svećenik držao u kući u selu Doganandzi, zaparavo Dogandzi (tur.), Rošlovo (mak.), danas Gerakorion u Grčkoj.

29 Usput rečeno, transkripcija turskog imena Skopja, Üsküp, treba glasiti Ускуп. Vidi https:// translate.google.com/\#auto/en/\%C3\%9Csk\%C3\%BCp.

30 Ovakvi se ,propusti“ ne mogu ničime opravdati, naručito od predstavnika zemlje koja je stoljećima uzor i pojam diplomacije. 
Uopće nije teško odgovoriti na to pitanje. Očito je da su razlozi politički. Nažalost, politika manje-više znanost stavlja u svoju službu. Primjer je i velika izložba o antičkoj Makedoniji u Muzeju Louvre 2011., na kojoj je dio antičkog Makedonskog Kraljevstva, koje obuhvaća današnja Republika Makedonija, prikazan kao terra incognita. ${ }^{31}$ Ako se i može shvatiti zašto političari „,ne smiju“ izgovoriti ime Makedonija kad se obraćaju Makedoncima kao gosti u njihovoj zemlji, nikako se to ne može razumjeti kad je u pitanju izložba o povijesnom događaju, koja bi morala biti rezultat znanstvenih istraživanja ${ }^{32}$ jer znanost ima drugačije zadaće $\mathrm{i}$ ciljeve nego politika.

Treća je nekorektnost najteža i sastoji se u tome da predstavnici europskih demokratskih zemalja ne spominju makedonski narod, ne samo na ovoj izložbi, već i tijekom svih manifestacija (posjeta grobljima i sl.), povezanih s obilježavanjem stogodišnjice početka I. svjetskog rata. Naime, kad se u brošuri (str. 10), kao i na prvome panou zdesna, nabrajaju vojnici koji počivaju na teritoriju Republike Makedonije, uopće se ne spominju makedonski vojnici. ${ }^{33}$

Uobičajen je odgovor na ovu primjedbu da nije bilo makedonske vojske. To jest točno, ali ne znači da nije bilo pukovnija makedonskih vojnika. U sastavu bugarske vojske borila se postrojba s imenom XI. makedonska divizija. ${ }^{34}$ Prema rodnim mjestima na nadgrobnim spomenicima, koji su rasuti po svim ratištima, jasno je da su to Makedonci. To osobito upada u oči na panou naslovljenom La diversité éthnique et culturelle de Macédoine, gdje piše da su u Makedoniji pretežno živjeli Makedonci, Bugari, Albanci, Grci, Srbi, Romi, Turci i Vlasi. Gdje su onda bili ti Makedonci i što su radili dok je u Makedoniji bjesnio rat i dok su ratovali svi oko njih? Naime, vrlo se dobro zna da su Makedonce u svoje vojske mobilizirale zaraćene balkanske države (Srbija, Bugarska, Grčka), koje su imale pretenzije prema Makedoniji i njezine stanovnike nazivale prema svojim nacionalnim ideologijama. I u Balkanskim ratovima bilo je postrojbi s makedonskim imenom. U sastavu srpske vojske 16. svibnja 1913. formiran je makedonski puk s četirima bataljunima sa zapovjednim mjestima u Gevgeliji, Negotinu i Prištini. ${ }^{35}$ Francuski političar, povjesničar i diplomat Victor Bérard ${ }^{36}$ pisao je o tome

31 DESCAMPES, LEQUINE I DR. 2011.

32 Gospođa Laurence Auer, ambasadorica Republike Francuske u Skopju, na moje me primjedbe o opisanim propustima izvijestila da je za obilježavanje stogodišnjice I. svjetskog rata bilo zaduženo znanstveno povjerenstvo povjesničara, na čelu s Antoineom Prostom (Dopis br. 2015 - 503745 od 29. svibnja 2015.).

33 Proslavama prisustvuju predstavnici Republike Makedonije. Makedonski su vojnici anonimni, a makedonski političari nijemi.

34 АПОСТОЛОВ 1993.

35 Архив војно-историског института Београд, popis 2, К-1 заповест ВК бр 132, мај 1913.

36 BÉRARD 1893: 160; Isti 1900. 
na zanimljiv način. Imenom Makedonaca nazivao je islamizirane Slavene, dok je kršćane prema crkvenoj pripadnosti pribrajao Grcima (patrijarhisti) ili Bugarima (egzarhisti). Kasnije, kad su ustrojene druge crkve, bilo je slučajeva u kojima su članovi iste obitelji popisani ne samo kao Grci i Bugari, već i kao Vlasi i Srbi. Naime, oni narodi koji su od Osmanlija dobili pravo na svoju crkvu u Makedoniji su otvarali škole, stoga su vjernike prema pripadnosti svojoj crkvi pribrajali svojem narodu. Zna se da crkvena pripadnost nije oznaka nacionalnosti, već je jedna od unutarnjih kulturnih sastavnica zajednice. ${ }^{37} \mathrm{Kršćanski} \mathrm{iseljenici} \mathrm{iz} \mathrm{Makedonije}$ uspjeli su 1791. u općini Buda postići da natpis grčke pravoslavne crkve bude promijenjen i dopunjen imenom Makedonija: The Ortodox Greek and Macedonian Church Municipality. ${ }^{38}$ Nakon podjele Makedonije novi su gospodari sustavno zamjenjivali svećenike i učitelje svojima, koji su provodili prisilnu asimilaciju stanovništva. Eklatantan je primjer grčkog vjerskog fanatizma grad Voden (Edessa), gdje je posljednja egzarhijska (bugarska) crkva konfiscirana, ikone slavenske Svete braće Ćirila i Metoda spaljene su, a njihov je pepeo prekriven izmetom. ${ }^{39}$

U Republici Makedoniji održavaju se groblja stranih vojnika I. svjetskog rata, a budući da su Makedonci ratovali u tuđim uniformama (kao i u Balkanskim ratovima), nema makedonskih grobalja. Makedonski vojnici leže zajedno s vojnicima stranih država koje su ratovale na makedonskom teritoriju. Na bugarskom su groblju u Novom Selu kod Strumice pokopani vojnici iz Božišća kod Bitole, Dušegubice kod Kičeva, Žilča kod Tetova, Psača kod Krive Palanke, Radoviša, Dojrana, Velesa, kosturskog i štipskog kraja itd. Rječit je primjer Atanasa Ivanova iz Novoga sela, koji je, kao vojnik, pokopan na bugarskom vojnom groblju, umjesto u nedalekoj obiteljskoj grobnici. ${ }^{40}$ Godine 2009 . Bugarskoj je uime dobrosusjedskih odnosa dopušteno obnavljanje vojnoga groblja u Novom Selu. Tom su prilikom obnovitelji postavili ploču s natpisom „Bugarska, ovi umriješe za te!“ (Българио, за тебе тие умреа) (Sl. 4). ${ }^{41} \mathrm{Na}$ svečanosti povodom obnove groblja, tijekom obreda (panihide) ${ }^{42}$ mjesno je stanovništvo izviždalo predsjednike obiju država (B. Crvenkovskog i G. Prvanova). Za razliku od drugih sudionika tih ratova, Bugarska ne traži dopuštenje samo za obnavljanjem grobalja, već svega što svjedoči o razdoblju bugarske vlasti - primjerice, fontane bugarskog cara Ferdinanda. Da

BART 1997: 214-259

38 Здравева, 2002: 95. Nakon austrijsko-osmanlijskog rata 1683.-1699. kršćanski iseljenici iz Makedonije registrirani su u Osijeku, Pešti, Zemunu itd.

39 KENNAN 1993 = KEHAH 2000: 183-245, više o grčkom nasilju vidi na str. 224-245; 237 (spaljivanje ikona); 57 (etnička pripadnost prema crkvi).

40 Глобус, br. 101, 24. III. 2009., 42.

41 To se dogodilo zato što Republika Makedonija, nažalost, još nije propisala standarde za uređenje vojnih grobalja stranih država.

42 Panihida, pravoslavna služba za mrtve, opijelo nad mrtvima (grč. pannykhís) 


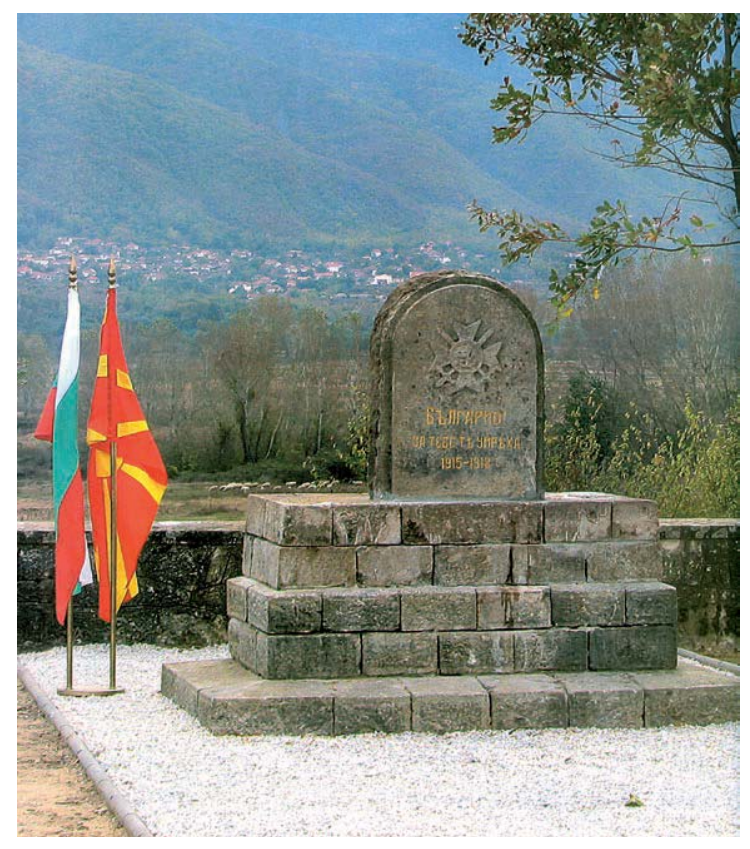

4. Spomenik na bugarskom groblju u Novom Selu, Strumica, snimio A. Stojčev.

ironija bude veća, ta se fontana u brošuri francuske ambasade nabraja zajedno sa spomenicima u čast poginulim vojnicima ${ }^{43}$ te se stječe dojam kao da Francuska podupire bugarske pretenzije prema makedonskom teritoriju. Svaka balkanska država koja je pod okupacijom držala neki dio Makedonije gradila je spomenike kako bi pokazala da je Makedonija njezina, a svaki je novi okupator rušio prethodno izgrađene spomenike i podizao vlastite. Tako je 1941. bugarska vojska u Štipu sa zemljom sravnila dvije zajedničke grobnice, koje su sagrađene tijekom srpske okupacije: jedna za vojnike srpske vojske, a druga za civile koji su umrli od kolere. ${ }^{44}$

Razumije se da je novačenje makedonskih vojnika bilo prisilno. Bilo je, međutim, i dobrovoljaca koji su se borili nadajući se oslobođenju i političkom osamostaljenju Makedonije. Na liniji bojišnice u bitolskom Mariovu još stoje rasuti nadgrobni spomenici, na kojima piše da su se pali vojnici borili za slobodu Makedonije (Sl. 5) ${ }^{45}$ Bezbroj je primjera koji svjedoče da je jedan brat unovačen u srpsku vojsku, kao npr. Stojan Арсевић, dok se drugi nalazi u bugarskoj vojsci

\footnotetext{
43 100 години прва светска војна 2014: 11.

44 Глобус, br. 101, 24. III. 2009., 42.

45 Na podatku i fotografiji zahvaljujem Gordani Filipovskoj-Lazarovskoj, dugogodišnjoj kustosici bitolskog muzeja.

46 НАЈДОВСКА И ПЕТРЕСКА 2008: 94-96, tri pisma Stojana Arsevića; na str. 97-98 nalazi se dopisnica koju je 1916. poslao Trajko Arsev.
} 


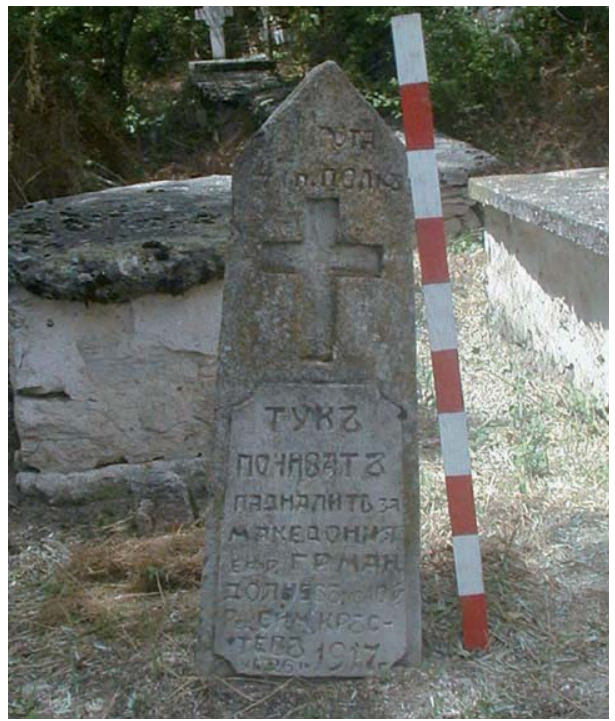

5. Nadgrobni spomenik vojnika palih za slobodu Makedonije na mariovskoj bojišnici, snimila G. Filipovska Lazarovska.

kao Trajko Арсевъ. ${ }^{46}$ Bugarske su se vlasti jedine koristile imenom Makedonije, nastojeći privući Makedonce najavljivanjem oslobođenja, a zapravo prikrivajući velikobugarski nacionalni koncept. Zbog toga su Makedonci uglavnom ratovali u sastavu bugarske vojske. Sačuvane su dopisnice vojnika XI. makedonske divizije, koja je ratovala upravo na makedonskoj (solunskoj) bojišnici. U knjizi Отпретани сведоштва objavljene su tri dopisnice vojnika ove divizije: Bogatina Angelova ${ }^{47} \mathrm{i}$ jedna Trajka Arsova. ${ }^{48} \mathrm{Na}$ žigu dopisnice koju je poslao vojnik Trajko Pešev piše da je služio u solunskom puku. ${ }^{49}$ Vojnik Miladin Nunev u adresi dopisnice piše da je služio u 4. makedonskom puku, žig dopisnice je nečitljiv. ${ }^{50}$ Stožer III. makedonske brigade XI. makedonske divizije u sklopu bugarske vojske izdao je jedan dokument (Д. 103) 20. listopada 1915. u Štipu. ${ }^{51}$ Lijep je primjer mobilizacije „lokalnog stanovništva“, koje se tako naziva na 10. panou, slika nadgrobne ploče vojnika Petka Liskovskog iz bitolskog sela Dobruševo, koji je ratovao kao turski, srpski i bugarski vojnik (Sl. 6). ${ }^{52}$ To pokazuje kako su

\footnotetext{
47 Isto: 68-71, Д.К. 107: царство бьлгария 11 макед. дивиз. 9 рота оть 2 макед. п; Д.К. 129: царство бьлгария 11 макед. Дивиз. 9 рота... (nečitljiv dio žiga); Д.К. 109: царство бьлгария 11 макед. дивиз 9 рота... (nečitljiv dio žiga).

48 Isto: 98, Д.К. 160: царство бьлгария 11 макед. дивиз. 5 рота оть... (nečitljiv dio žiga).

49 Isto: 254 Д.К. 147: царство бьлгария. 13 рота 39 солунски полк.

50 Isto: 470 , Д.К. 118.

51 Isto: 542, Д. 103.

52 ЗДРАВКОВСКА, Дневник, br. 5227, Skopje, 27. - 28. srpnja 2013., 4.
} 


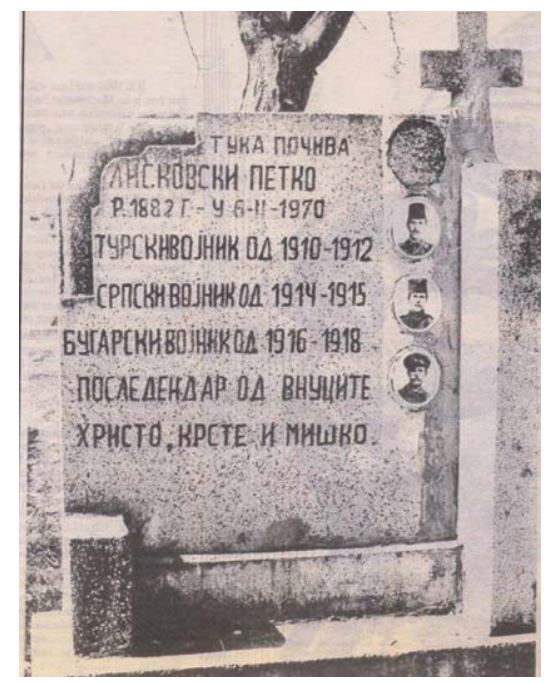

6. Nadgrobni spomenik vojnika P. Liskovskog u selu Dobruševu. Snimila Z. Zdravkovska.

i autori izložbe svjesni da su Makedonci u ovome ratu ginuli za tuđe interese, ali to izbjegavaju iskazati. Na istom panou piše da su se u sukob dobrovoljno uključivali drugi stanovnici ,komiti (comitadjis) ${ }^{53}$, članovi VMRO-a ${ }^{54}$ i albanski plaćenici“. Kako se vidi, plaćenici imaju nacionalnu pripadnost, dok komiti, članovi Unutrašnje makedonske revolucionarne organizacije, osnovane s ciljem oslobađanja Makedonije, nemaju etničko ime. Ime organizacije ukazuje na razlog njezina osnivanja, a dobro se zna tko ju je, kada i gdje formirao. Sve ovo jasno pokazuje da se sustavno i svjesno izbjegava makedonsko ime. ${ }^{55}$ To se moglo veoma elegantno postići barem spominjanjem vojnika iz Makedonije ili urođeničkih vojnika - Aboridžina. ${ }^{56}$ Susjedi su na teritoriju Republike Makedonije slobodno slavili i stogodišnjicu Balkanskih ratova. U listopadu 2012. srbijanski je predsjednik Tomislav Nikolić, odajući počast srpskim vojnicima koji su pali

$\overline{53}$ Komiti su se u izvorima često označavali kao bugarski jer se nakon propasti Samujlova carstva za Makedonce koristilo bugarsko ime, ali ne s etničkim, već s državno-pravnim značenjem. Vidi ПРОЕВА 2000: 8-16.

Unutarnja makedonska revolucionarna organizacija.

55 Vjerojatno zbog toga na službenoj najavi aktivnosti za obilježavanje stogodišnjice početka 1. svjetskog rata, koja je započela predavanjem „1914 - 2014: les Balkans, 100 ans après le début de la Première Guerre Mondiale“, nije bilo nijednog etničkog Makedonca, što se vidi iz obraćanja francuske ambasadorice u Skopju, kao i prema imenima službenih osoba kojima se ona obraća (vidi stranice Ambasade).

56 Izbjegavanje je spominjanja žrtava lokalnog, aboridžinskog stanovništva svetogrđe prema njima i uvreda njihovih potomaka i od zemlje čiji vojnici počivaju na makedonskom tlu te čiji se spomen u samostalnoj makedonskoj državi danas slobodno štuje. 
u bitci kod Kumanova, izjavio da te događaje treba obilježavati zajedno jer su Balkanski ratovi bili oslobodilački te da su se Srbi u njima borili za oslobođenje kršćanske braće od turske vlasti. ${ }^{57} \mathrm{Kad}$ je vardarska Makedonija pridružena Srbiji, Makedonci su nazvani Južnim Srbima ${ }^{58}$, a Makedonija se nazivala Starom ili Južnom Srbijom. ${ }^{59}$ Zamjenjivanje jednoga ropstva drugim ne može se nazivati slobodom. Razumije se da je bilo reakcija na tu izjavu, nažalost, ne od makedonskih političara (barem ne javno), u smislu da Makedonija nema zašto slaviti Balkanske ratove ${ }^{60}$, pri čemu se isticalo i da srpska crkva Makedoncima ne dopušta obilježavanje godišnjice ASNOM-a ${ }^{61}$ u manastiru Prohor Pčinjski ${ }^{62}$, koji je od 1946. potajno uključen u teritorij Republike Srbije. ${ }^{63}$

Povjesničari susjednih zemalja, braneći nacionalne ideologije, „dokazuju“ da tada, prije sto godina, Makedonci nisu bili nacionalno osviješteni. Nazivaju ih amorfnom masom, što jedan broj zapadnoeuropskih povjesničara prihvaća, a političari ponajprije. Time očigledno žele opravdati tadašnju politiku, koju iz nerazumljivih razloga ove zemlje i danas provode. Sačuvanim dokumentima takve se tvrdnje lako pobijaju. Ruska carica Elizabeta/Jelisaveta Petrovna (1709.1762.) izdala je 24. prosinca 1752. ukaz (carsku gramotu) kojom se makedonskim, bugarskim, vlaškim i drugim kršćanima dozvoljava naseljavanje u Rusiju i formiranje pukova koji su raspoređeni na osmansko-tatarskoj granici. ${ }^{64}$ Nakon austrijsko-turskog rata, 1759. od makedonskih je preseljenika u Rusiju (sela imaju makedonska imena: Nov Polog, Skopsko Selo, Makedonsko Selo, Kumanovo itd. $)^{65} \mathrm{u}$ Ukrajini oblikovan makedonski puk ${ }^{66}$, koji je imao vlastiti pečat, zastavu i uniformu s makedonskim oznakama, grb i amblem (lav kao u Hrestomatiji

57 НИКОЛИК, Дневник, br. 5000, 29. Х. 2012., 3; АДАМОВСКИ, Утрински весник, br. 4018 , 29. X. 2012., 3.

58 Ukaz o ,javnoj sigurnosti“, koji je srpska Vlada donijela 21. rujna/4. listopada 1913. za tzv. „proširenu Staru Srbiju“, u cijelosti je objavljen u izvješću Carnegijeva balkanskog povjerenstva, КЕНАН 2000: 196-199, kao i komentar ukaza iz časopisa Радничке новине. I iz Ukaza i iz reakcija na nj vidi se da se nije radilo o ujedinjenju srpskih zemalja, već o okupiranju tuđeg teritorija i nesrpskog stanovništva. Isto: 199, 200. O nasilju srpskih vlasti vidi Isto: 194-224, glava II., pogl. 2: Srpska Makedonija.

ЦВИЈИЋ 1931. Osim „проширеном Старом Србијом“, Makedonija se na srpskim zemljovidima nazivala i „Младом Србијом“, КЕНАН 2000: 57, a ponekad i „Новом Србијом“, Isto: 222.

60 ТРАЈКОВСКА, Дневник, br. 5000, 29. Х. 2012., 3.

${ }^{61}$ Antifašističko vijeće narodnog oslobođenja Makedonije

62 ЗАРЕВСКА, Нова Македонија, br. 22984, 23. IX. 2013., 2.

63 O povijesti manastira vidi ЏИКОВ 2000; ПЕРИЌ 1988.

64 ХРИСТОВ И ДОНЕВ 1994: 16.

65 ЗДРАВЕВА 2005: 135-145.

66 МАТКОВСКИ 1985: 550. 
Dojrančanina Hristifora Žefaroviča) ${ }^{67}$ Ruska carica Katarina II. (Yekaterina II. Velikaya, 1762. - 1796.) piše 10. (21). rujna 1782. pismo austrijskom caru Josipu II. o uspostavljanju Grčkoga Carstva, koje bi tvorile Bugarska, Makedonija i dio Albanije. ${ }^{68}$ Još 1905. sedmorica učitelja u Bitoli pokušala su napisati gramatiku makedonskog jezika prema narječjima Bitolskog vilajeta ${ }^{69} \mathrm{O}$ različitosti Makedonaca, kako od Bugara, tako i od Srba, u znanosti se raspravljalo još od kraja 19. stoljeća $^{70}$, a treba spomenuti i zapadne izvjestitelje s terena tijekom Balkanskih ratova. ${ }^{71}$ No, iz vremena I. svjetskog rata potječu svjedočanstva stranih autora, koji navode izjave djece i staraca s terena o njihovoj nacionalnoj pripadnosti. ${ }^{72}$ Treba spomenuti i metode nasilnoga mijenjanja nacionalne svijesti Makedonaca. Naime, nakon Balkanskih ratova makedonsko se stanovništvo prisiljavalo na potpisivanje izjava da je prethodno izjašnjavanje bilo prinudno. ${ }^{73}$

Važno je također imati na umu da je nacionalno buđenje balkanskih naroda počelo tijekom borbe protiv osmanskih vlasti uz pomoć velikih sila (najočigledniji su primjer za to $\mathrm{Grci})^{74} \mathrm{i}$ da europski koncept o nacijama nije primjenjiv na Balkanu. ${ }^{75}$ U osmanskom razdoblju nazivi Bugarin, Grk, Srbin nisu imali etničko i nacionalno značenje, već socijalno ili vjersko: Grk = pravoslavni kršćanin i trgovac; Bugarin = slavenski seljak, ratar, vrtlar itd. ${ }^{76}$ Čak i u Bugarskoj ime Bugarin nije imalo nacionalno značenje, već je bilo sinonim za kršćanina. Bugari pak, koji su živjeli u gradovima, zbog prezira Grka prema njima sami su sebe nazivali Elinima. ${ }^{77}$

\footnotetext{
67 Stematografija ili Izobraženije oružij iliričeskih 1741., grb Makedonije. i mnogi drugi.

71 REISS 1918: 6-7; BOUCHIÉ DE BELLE 1922; BARBUSSE 1926: 50-54, pogl. „Le comité macédonien, Le problème de la Macédoine“ (140-144); reakcije na knjigu objavljene su u časopisu La Féderation Balkanique, br. 51, 1. IX. 1926: 871; BARBUSSE 1926a: 867; Isti i u Monde, br. 108, 28. VI. 1930., 2. O Barbusseovu djelovanju vidi HACTEB 1965-1966: 205234.

72 LEBEDEV 1917: 136, 140-141; BURNET 1921: 80; NOBIS 1919: 95-96 i mnogi drugi. Na jednoj austrijskoj dopisnici za ratne zarobljenike u rubrici za rodno mjesto vojnika Stojana Panova napisano je skraćeno Mazedon. (НАЈДОВСКА И ПЕТРЕСКА 2008: 336, Д.К. 140).

73 KEHAH 2000: ljude u Kosturu (235), kao i u Vodenu (237) tjeralo se da izjavljuju kako su od najstarijih vremena bili Grci, ili pak da su 1903. bili Elini, ali da su između 1903. i 1906. pod prijetnjom bugarskih bandi i komita prisiljeni izjašnjavati se kao Bugari. I muslimane koji nisu govorili turski proglašavalo se Grcima (236). Srpske su pak vlasti egzarhiste u Makedoniji tjerale da potpišu da su Srbi $(210,318)$.

74 STEPPAN 2004, glava 2. 3; СТЕПАН 2004: 105-129.

75 Pregled teorija o nacijama i nacionalizmu vidi u KATUNARIĆ 2003: 139-193.

76 БАЛАН 1904: 818; МЛАДЕНОВ 1985: 3-11; FRIDМАN 2000 (ФРИДМАН 2003: 247).

77 БАЛАН 1978: 29-30; BALAN 1978: 28-29.
} 
Naime, u Osmanskom Carstvu nije se priznavala nacionalna, već vjerska pripadnost. ${ }^{78}$ Slavenski su muslimani sebe nazivali Turcima, iako nisu govorili turskim jezikom. ${ }^{79}$ Prvi su put u popisu 1905. osmanske vlasti odredile da se stanovništvu Makedonije, osim vjere, bilježi i nacionalnost. Zainteresirane susjedne države nastojale su imati predstavnike u povjerenstvima kako bi se stanovnici popisivali prema kriteriju koji je za njih bio najpovoljniji: Grci su se nastojali popisivati prema vjeri, a Srbi i Bugari prema nacionalnosti, suglasno sa svojim interesima. Bugari su čak tražili da se o pripadnosti ne pita muškarce, koji su znali više jezika, već žene, koje su u najvećem broju slučajeva znale samo svoj materinski jezik - makedonski - koji je za Bugare bio bugarski. ${ }^{80}$ Ruski konzul u Bitoli, G. Kalj, dalje piše kako mnogi nisu znali svoju nacionalnost, drugi se pak zbog prijetnji i nasilja neće izjasniti, dok će treći to prikriti. Žitelji jednoga sela u Prilepskoj kazi odbili su reći svoju nacionalnost i tražili da ih se popiše kao Turke jer su se bojali da će ih poklati srpske ili turske bande. ${ }^{81}$ Zbog prijetnji grčkog metropolita o njihovu isključivanju iz crkve Vlasi jednoga sela izjasnili su se Grcima, ali su sutradan telegramom o tome izvijestili turske vlasti. ${ }^{82}$

Očigledno je da tajanstveno francusko povjerenstvo, koje je pripremalo izložbu, nije surađivalo s makedonskim povjesničarima ${ }^{83}$ Oni su im mogli ukazati na izvorne dokumente koje su pisali domaći vojnici, a pokazuju da su Makedonci ratovali u vojskama susjeda koji su ih prisvajali. Samo su bugarske vlasti, uz materijalnu pomoć njemačkih i austrijskih vlasti, tijekom rata na teritoriju Makedonije mobilizirale ukupno 133.887 vojnika ${ }^{84}$ Najbrojniji (122.000) bili su

78 U 15. stoljeću u Osmanskom su se Carstvu po vjeri priznavala tri mileta (naroda), koji su imali (vjersku) knjigu: Rumski milet (pravoslavni kršćani); Hebrejski milet i Armensko-gregorijanski milet. Imenom Рум милет označavali su se kršćani za koje je bio odgovoran carigradski patrijarh te je ime Rumeliot postalo sinonimom za Grka, a prema vjeroispovijesti stanovništva, zemlje Trakija, Makedonija, Epir i Tesalija nazivale su se zajedničkim imenom Rumelija. ЦЕПЕНКОВ 1972: 132-134.

80 Izvješće ruskog konzula u Bitoli, vidi ЧЕПРЕГАНОВ 2010: 169.

81 Nakon neuspjeha Ilindenskog ustanka (1903.), krize i raskola u VMRO-u, susjedne su države ubacivale čete na teritorij Makedonije: srpske četnike, bugarske komite i grčke andarte. Oni su terorizirali civilno stanovništvo te su se, zajedno s crkvenim organizacijama, borili za pridobivanje makedonskog kršćanskog stanovništva za svoje cause. Izvješće ruskog konzula u Bitoli, vidi ЧЕПРЕГАНОВ 2010: 169. Zbog toga su se u Parizu, Londonu i Beču formirala povjerenstva za zaštitu žrtava od tzv. „bijelog terora na Balkanu“, o kojemu svjedoče strani izvjestitelji. ЧЕПРЕГАНОВ 2010: 170.

83 Ovo je neshvatljivo, posebice zato što Francuska ima iskustvo u muzejskoj suradnji sa susjedima. Vrlo je lijep primjer upravo za I. svjetski rat memorijalni kompleks, otvoren 1992. u dvorcu Péronne (Mémorial de Péronne), koji su zajedno uredili francuski, njemački i engleski povjesničari. Ondje su ravnopravno prikazane i vojne i civilne žrtve rata. U okviru trogodišnjeg (2001-2003) makedonsko-francusko-njemačkog seminara za studente (Историјата видена со очите на другиот / Geschichte: Mit anderen Augen betrachtet / Histoire vu par les yeux des autres) ovaj smo muzej posjetili 2002 god. i predstavili ga studentima triju zemalja kao primjer povijesnog iskustva. 
vojnici upravo iz vardarskog dijela, današnje Republike Makedonije, gdje se odaje počast žrtvama stranih vojski, no uz potpuno prešućivanje makedonskih žrtava (kao na ovoj izložbi). U egejskom dijelu Makedonije mobilizirano je 4.237 vojnika, a u pirinskom $17.000 .{ }^{85} \mathrm{U}$ sastavu srpske vojske prvim je pozivom mobilizirano 12.000 vojnika, a u drugom i trećem 53.048 u pješadijske pukove s imenima triju divizijskih oblasti (vardarska, bregalnička i bitolska), koje su tada bile u sklopu Srbije. Do kraja rata ukupno je mobilizirano 65.048 osoba iz vardarskog dijela Makedonije, od koji su 56.258 bili Makedonci, 8.471 muhamedanci (Turci i Albanci), a 319 Hebreji. ${ }^{86}$ Najmanji je broj mobiliziranih bio u grčkoj vojsci, oko 20.000 Makedonaca $^{87}$, koji su odande dezertirali bježeći u druge zemlje ili se priključivali vojskama susjeda. Bilo ih je koji su dezertirali u savezničke vojske, među kojima i u francusku. ${ }^{88}$ Inače, od početka rata sve do lipnja 1918. Grčka je bila neutralna i neprijateljski raspoložena prema Francuskoj i njezinim saveznicima ${ }^{89}$ Tim je teže shvatljiva šutnja autora izložbe o sudjelovanju Makedonaca u ratu. ${ }^{90}$

Od neprocjenjive je vrijednosti za sudjelovanje Makedonaca u I. svjetskom ratu zbirka dokumenata koju je 2000. otkupila fondacija Foundation Open Society Macedonia - Институт Отворено општество на Македонија. Zbirka obuhvaća 257 pisama, 59 vojnih i civilnih dopisnica, 3 spisa i 29 novčanica. Tijekom pročišćavanja vojnog arhiva Generalštaba bugarske vojske u Sofiji rukovodilac I. V., rođen 1918. u Štipu, spasio ju je i zakopao u metalnoj kutiji u vinogradu kod Ćustendila u Republici Bugarskoj. ${ }^{91}$ Činjenica da se sva ta pošta našla na istome mjestu u bugarskom vojnom arhivu upućuje da nikada nije stigla do primatelja. Dopisnice su prošle austrougarsku i bugarsku cenzuru, što se vidi po pripadaju-

85 Na istome mjestu.

86 Arhiv Vojnoistorijskog instituta u Beogradu, Фонд Први светски рат, АВИИ, Пописник 7, kut. 58, br. 2/2, fasc. 1, 1.1 (citirano prema A. STOJČEVU, kojemu zahvaljujem).

CTOJAHOB 1969: 238.

\section{BOURLET 2002: 60-61.}

\section{ЛАЕ 2003: 83-85}

90 A. Stojčev podrobno je obradio sudjelovanje Makedonaca u I. svjetskom ratu u knjizi Македонскиот фронт 1915-1918 te u članku „Македонскиот фронт и македонскиот национален идентитет во првата светска војна“", u: Македонија и Македонците во првата светска војна, Скопје 2014. Oba su djela u tisku. Neshvatljivo je zašto nije uključen u pripremu izložbe, tim više što je i sam muzealac - obavlja dužnost ravnatelja Vojnog muzeja u Skopju.

91 О zbirci vidi НАЈДОВСКА И ПЕТРЕСКА 2008: 9, 17-19. Zbirka je objavljena gotovo u cijelosti, ali kao građa, pri čemu dokumenti nisu uvijek pročitani cjelovito, što se vidi po fotografiji koja prati svaki dokument. Prije obrade dokumenti su numerirani arapskim brojem, dok su u knjizi prikazani kronološki, ali u okviru dvije regije (Kratovske i Probištipske), što otežava njihovo korištenje. Д.К. označava dopisnice, а Д. П pisma, dok su ostali dokumenti ekonomskog karaktera označeni slovom Д. - jedino ova grupa dokumenata nije u cijelini prikazana. 
ćim pečatima, ${ }^{92}$ a na nekima je i poštanski žig makedonskog grada, ${ }^{93}$ a ipak nisu isporučene, što znači da je djelovala i neka treća, stroža cenzura.

Primjerke iz ćustendilske zbirke pisali su vojnici i ratni zarobljenici koje su srpska i bugarska vojska prethodno mobilizirale u sjeveroistočnom dijelu Republike Makedonije (kratovski, probištipski i zletovski kraj). Dopisnice su tiskane u Bugarskoj ${ }^{94}$, Srbiji ${ }^{95}$ i Austro-Ugarskoj ${ }^{96}$ za vojnike i ratne zarobljenike, koji su se njima morali koristiti za korespondenciju s obiteljima. Bugarske $\mathrm{k}$ tome nose i žig vojne jedinice. ${ }^{97} \mathrm{U}$ pismima i na dopisnicama koje su vojnici slali s fronte ili iz logora u Austro-Ugarskoj ne samo da su toponimi slavenski (Skopje), a ne turski (Uskup), već je pošta adresirana na Makedoniju - tout court, kako bi rekli Francuzi. Adrese dopisnica tiskanih u Srbiji i Bugarskoj, osim imena sela i okruga, rijetko nose ime zemlje u koju se šalju ${ }^{98}$, a ako ga i imaju, najčešće stoji Makedonija, rjeđe Nova Bugarska ili Srbija. Na samo jednoj austrijskoj dopisnici nema imena zemlje. ${ }^{99}$ C̆ak i bugarske tiskane dopisnice koje su vojnici slali svojim obiteljima adresirane su na Makedoniju (S1. 7 ). ${ }^{100}$ Neke su austrougarske

$\overline{92}$ Trokutasti austrougarski žig bečkog odjeljka: K u. K. Gemeinsames / Zentr. Nachw. Euro / Zensur Abteilung-Wien; okrugli srpski s natpisom : Прегледала војна цензура; okrugli bugarski: цензурна комисия, s imenom grada (Свищовь, София, Пловдивь, Ески Д..., Дедеагачь, Скопие, drugi su manje čitljivi), gdje je očito obavljenja završna cenzura i dopisnice su vraćane natrag, pa to objašnjava zašto su se našle u bugarskom vojnom arhivu u Sofiji.

93 Imena gradova na žigovima su pisana ćirilicom i latinicom. Kratovo: Д.К. 113, 129, 109, 107, 144, 136, 143, 158, 117, 127, 148, 130, 147, 137, 112, 118, 163, 125, 121; Скопие, Д.К 152, 116; Sv. Nikola Д.К. 140; Радомир Д.К. 122, Куманово, Д.К. 153, 115 159, 161; Дебар Д.К. 126. Neke dopisnice imaju po dva poštanska žiga Д.К. 129, 118, 137 (Kumanovo i Kratovo), Д.К 127 (Kratovo i Strumica), Д.К. 124 (Prisren i Kratovo).

Bugarske vojne i građanske dopisnice nose grb, ali je na prednjoj strani vojnih (военна) и vojničkih (воинишка) otisnuta opomena o čuvanju vojnih podataka: ako ih ima, dopisnica će biti uništena.

95 Na srpskim je dopisnicama, koje je tiskala Inspekcija pošte srpskih armija (Издаъе Инспекиије Пошта српских армија), u boji otisnut grb, iznad piše Kraljevina, a ispod Srbija. Na gornjem rubu poleđine otisnuto je: Писати се могу само приватне вести. Карта ће бити униттена, ако се излажу војничке ствари.

96 Austrougarske dopisnice nose naslov Feldpostkorresponenzkarte ili Kriegsgefangenen-Korrespondenzkarte. Prve su izvorno namijenjene austrougarskim aktivnim vojnicima, pa predviđaju mjesto za ime pošiljatelja na sedam - osam jezika (Absender, Odesilatel, Nadawca, Mittente, Pošiljatelj, Pošiljač i Presentator). Na njima se nad tiskanim naslovom ponekad dodavao žig koji je korisnika definirao kao ratnog zarobljenika. One koje su se namjenski tiskale za ratne zarobljenike sprijeda imaju čitav formular s mjestom zarobljeništva, koji iziskuje dodavanje podataka o postrojbi kojoj je zarobljenik pripadao, njegovu mjesto rođenja i broju pod kojim je evidentiran.

97 НАЈДОВСКА И ПЕТРЕСКА 2008: Д.К. 159, 129, 109, 107, 108, 138, 144, 158, 161, 134 , 145, 130, 147, 152, 137, 153, 131, 162, 105, 156, 118, 146, 154.

98 Očito je da vlasti nisu smatrali potrebnim staviti ime "svoje“ zemlje, tj. države. 


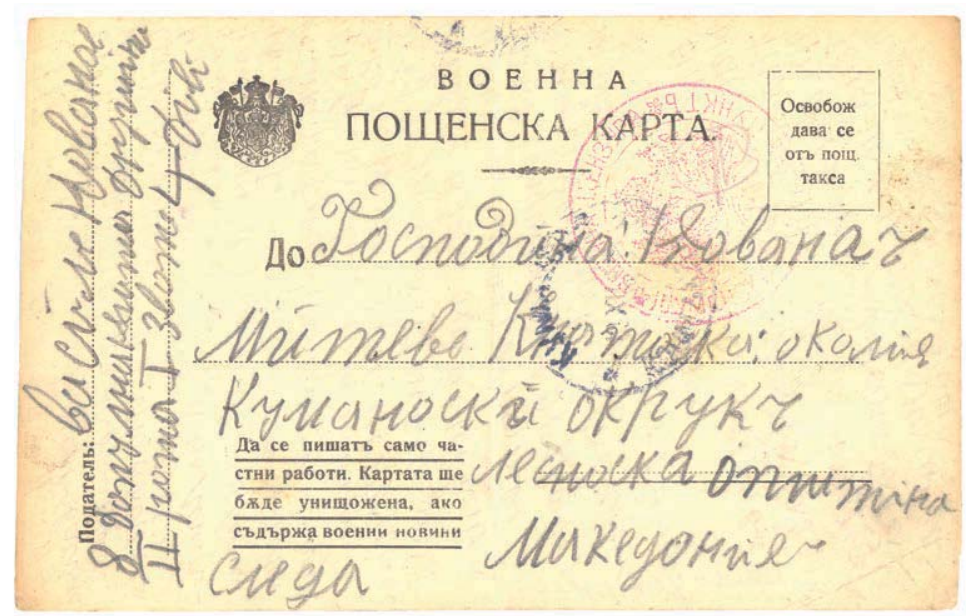

7. Bugarska vojna dopisnica adresirana u Makedoniju, НАЈДОВСКА И ПЕТРЕСКА 2008: Д.К. 115.

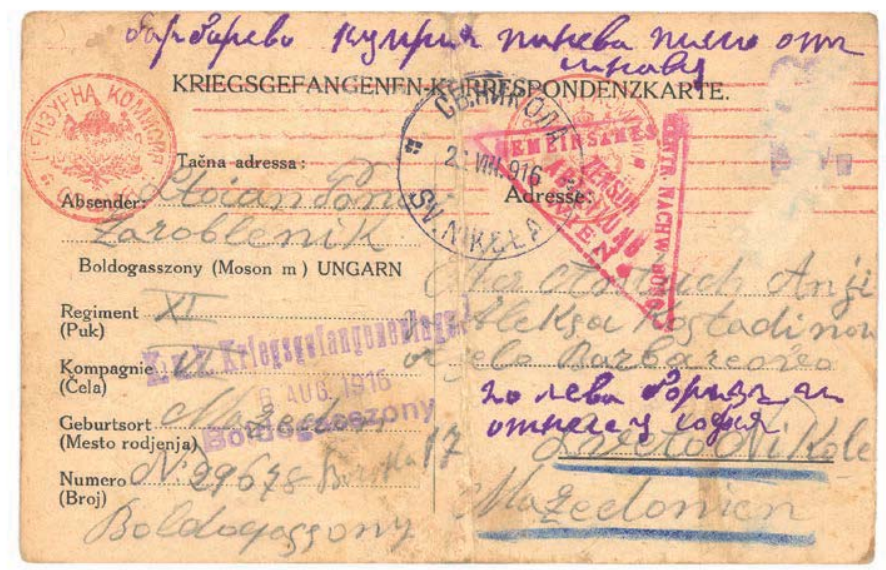

8. Austrougarska vojna dopisnica sa dvojezičnim rubrikama adresirana u Makedoniju, НАЈДОВСКА И ПЕТРЕСКА 2008: Д.К. 140.

dopisnice adresirane samo sa oznakom Mazedonien, kao što je na vojnoj dopisnici koju je poslao Stojan Panov - zarobljenik iz sastava srpske vojske. Dopisnica je tiskana dvojezično, njemački i srpski; kao mjesto rođenja upisano je Mazedon., a kao adresa selo Barbarevo, Sveto Nikole, Mazedonien. Kako pokazuje poštanski žig, dopisnica je u Sv. Nikolu stigla 20. kolovoza 1916. (S1. 8). ${ }^{101}$ Na nekim je austrougarskim vojnim dopisnicama ispred primateljeva imena otisnut crveni žig s imenom MAZEDONIEN, a na jednoj je žig crn. Na nekima su pošiljatelji u

$\overline{101}$ Isto: 336, Д.К. 140. 


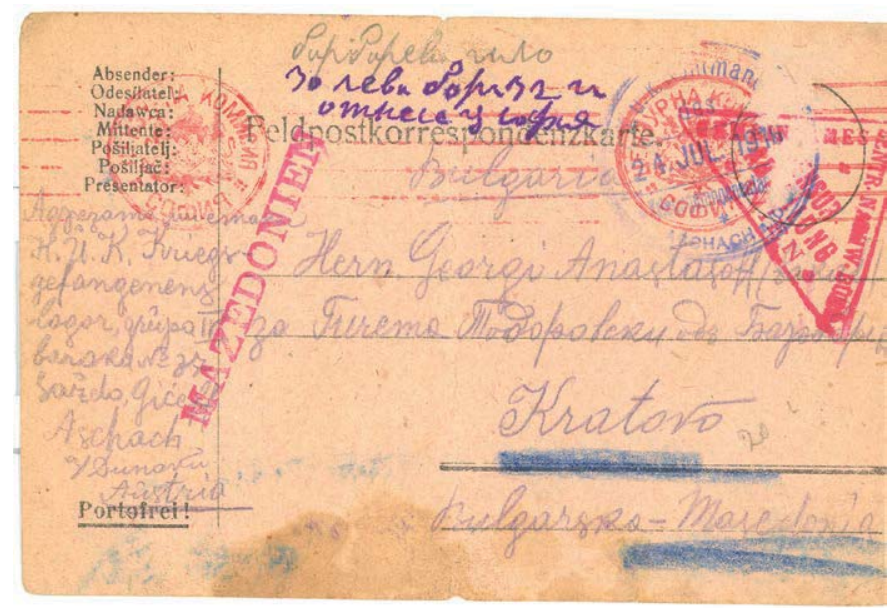

9. Austrougarska vojna dopisnica adresirana u Makedoniju sa pridjevkom bugarska, НАЈДОВСКА И ПЕТРЕСКА 2008: Д.К. 142.

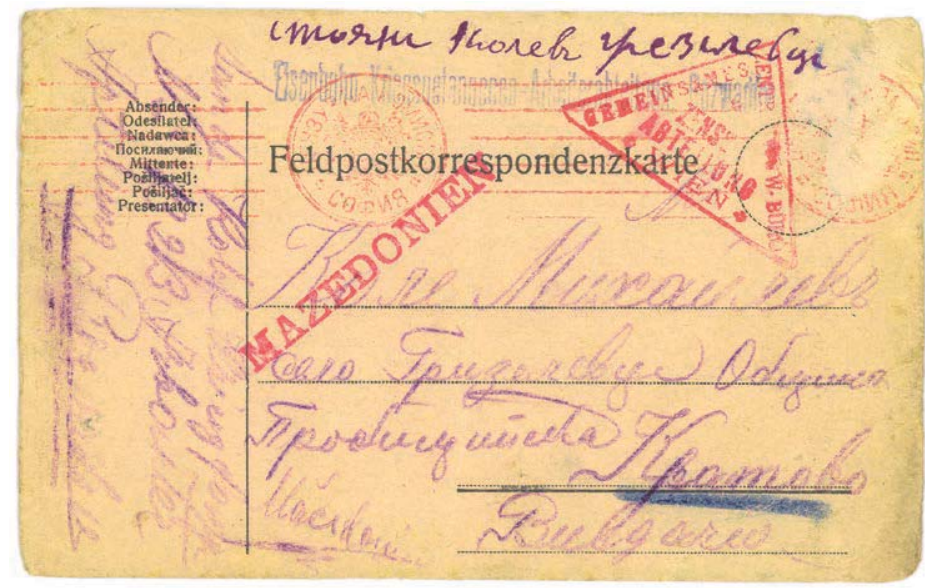

10. Austrougarska vojna dopisnica adresirana u Bugarsku s dopisanim imenom Macedonia i crvenim žigom MAZEDONIEN, НАЈДОВСКА И ПЕТРЕСКА 2008: Д.К. 133.

adresi rukom precizirali „Bulgarska Makedonia (S1.9)“102 ili pored imena Bulgaria dopisali ime Macedonia ${ }^{103}$ Od triju austrougarskih dopisnica, dvije imaju crveni žig MAZEDONIEN, jedna je adresirana na Bugarsku Makedoniju, ${ }^{104}$ druga je upućena u Makedoniju, a ispod je dopisano Bugarija. ${ }^{105}$ Adresa treće završava

\footnotetext{
102 Isto: 146, Д.К. 110; 332, Д.К. 142.

103 Isto: 211, Д.К. 139; 212, Д.К. 134; 246, Д.К. 135; 492, Д.К. 123. Posljednja je poslana iz južne Češke iz mjesta Lhenica/Lehenitz sa crvenim žigom MAZEDONIEN.

104 Isto: 332, Д.К. 142.

105 Isto: 492, Д.К. 123.
} 


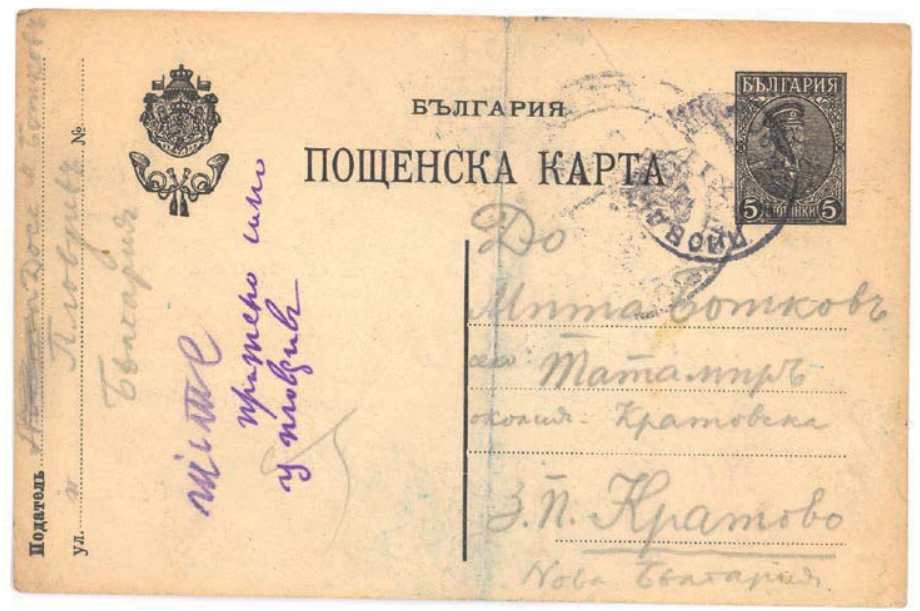

11. Bugarska vojna dopisnica adresirana u Novu Bugarsku, НАЈДОВСКА И ПЕТРЕСКА 2008: Д.К. 145.

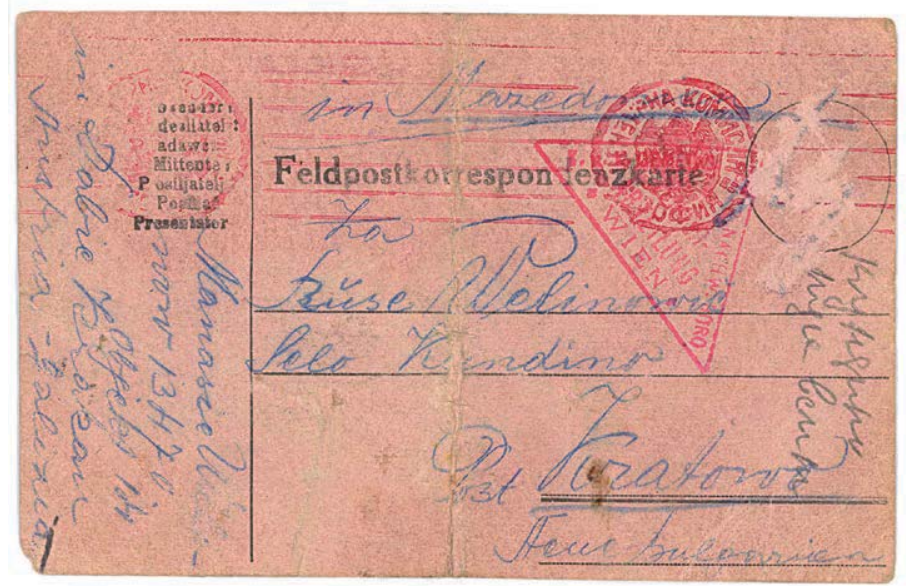

12. Austrougarska vojna dopisnica adresirana u Neue Bulgarien, a iznad adrese dopisano in Mazedonien, НАЈДОВСКА И ПЕТРЕСКА 2008: Д.К. 119.

latiničnim imenom zemlje, Bulgaria, ispred kojega je dopisano i podvučeno Macedonia (Sl. 10). Na jednoj je ime Macedonia ukoso napisano pokraj imena Bulgaria te je udaren crveni pečat MAZEDONIEN. ${ }^{106}$ Dvije tiskane bugarske dopisnice poslane su u Kratovo, koje se nalazi u Novoj Bugarskoj (Нова Бьгария) (Sl. 11). ${ }^{107}$ Samo je jedna austrougarska dopisnica, poslana iz Donjeg Krakova (Austrija,

\footnotetext{
106 Isto: $146,332,212,428$.

107 Isto: 238 , dol. br. 145.
} 


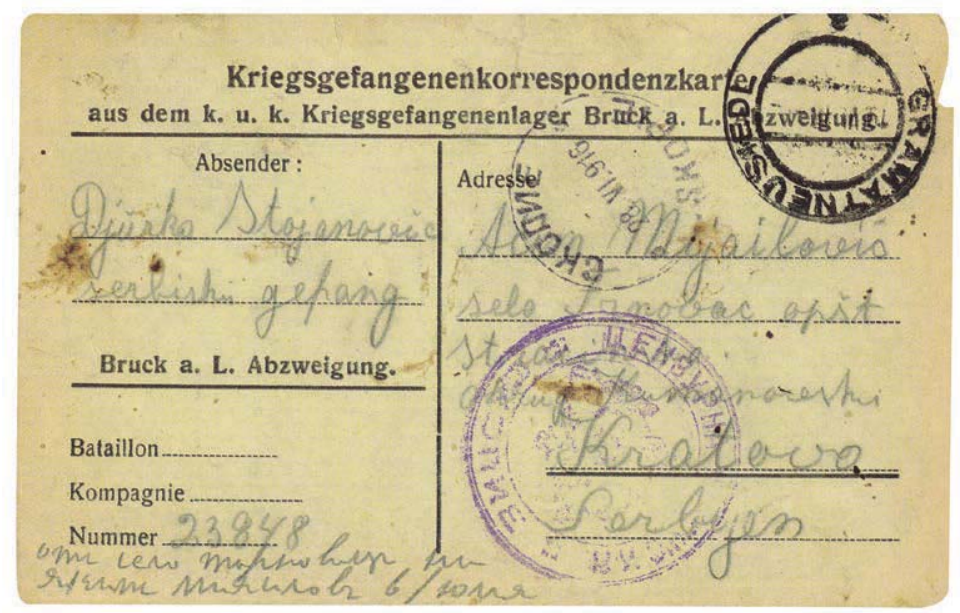

13. Srpska vojna dopisnica, НАЈДОВСКА И ПЕТРЕСКА 2008: Д.К. 116.

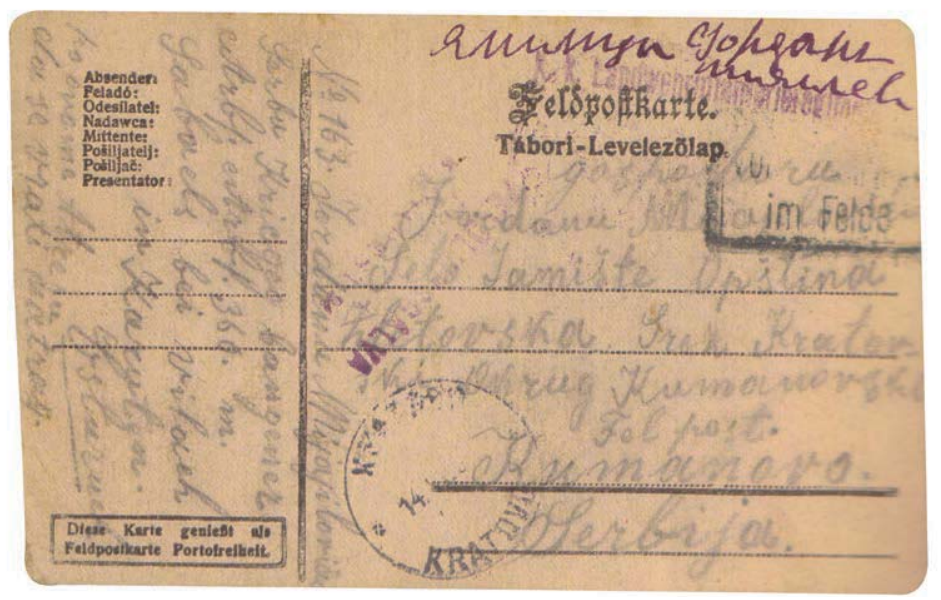

14. Srpska vojna dopisnica, НАЈДОВСКА И ПЕТРЕСКА 2008: Д.К. 163.

Galicija), upućena u Neue Bulgarien. Iznad adrese napisano je in Mazedonien, čime se želi reći da je Kratovo u Makedoniji (S1. 12). ${ }^{108}$ Samo jedna dopisnica, poslana iz austrougarskog logora u Kratovo, upućena je u Bulgarien ${ }^{109}$, a desno od adrese udaren je crni pečat MAZEDONIEN. Ime se Srbija na dopisnicama sreće samo dvaput: jedna austrougarska dopisnica iz zarobljeničkog logora Dolni Bruk nosi tri pečata: austrougarske i bugarske cenzure u Skopju te poštanski žig grada Скопие. Upućena je u Serbijen (S1. 13). ${ }^{110}$ Drugu je poslao Jordan Mijajilović,

\footnotetext{
108 Isto: 468, Д.К. 119.

109 Isto: 500, Д.К. 150.

110 Isto: 274, Д.К. 116.
} 
zarobljenik iz srpske vojske, Jordanu Mijajlevu u selu Jamištu, općina Zletovo, srez Kratovo, Fel. Post Kumanovo, a ispod piše Srbija. ${ }^{111}$ Dopisnica je posebno rječita jer je iznad adrese crvenom tintom ime primatelja i sela napisano ćirilicom u bugarskoj verziji (Sl. 14).

Nekoliko dopisnica čini eksplicitan primjer asimiliacije stanovništva. Jednu je vojniku srpske vojske Petru Vukanoviću (Петре Вукановић) poslao otac Vukan Ilić (Вукан Илић) iz sela Sakulica, a tekst je - u suprotnosti sa srbiziranim prezimenima - na lokalnom makedonskom narječju. ${ }^{112}$ Drugu je isti vojnik, sada zarobljenik, napisao 12. ožujka 1916. u austrougarskom logoru u „Bohemiji“, sada s prezimenom ispisanim po bugarskom pravopisu, kao Petre Vukanov (Пempe Вукановъ), ocu Vukanu Ilievu (Вукан Илиевъ). Dio adrese ispisan je latinicom (Kratovo), a dio ćirilicom (Македония), dok je iznad adrese latinicom dopisano Bulgarija. ${ }^{113}$ Isti bivši srpski vojnik kao austrougarski zarobljenik 25. lipnja 1916. ocu Vukanu Ilievu (Вукан Илиев) šalje drugu dopisnicu na lokalnom makedonskom narječju s primjesama srpskoga, latiničkim pismom. Adresa je selo Sakulica, Macedonija, Bulgarija. ${ }^{114}$

Dopisnice su na lokalnom makedonskom narječju, rjeđe na lošem srpskom ili bugarskom jeziku, ovisno o tome u kojoj je vojsci bio pošiljatelj. Na dopisnici koju je otac poslao vojniku Todosu Pešiću (Тодос Пешић), koji je 1915. mobiliziran u srpsku vojsku, on je oslovljen kao бaŭ (gospodin), ali je riječ ispisana fonetski, бaj. ${ }^{115}$ Tekst je mješavina srpskih i makedonskih riječi. Kad Todos 1917. piše ocu na bugarskoj vojnoj dopisnici, potpisuje se kao Teodos Pešev (Teodoç Пешевъ ${ }^{116}$ Jednako je s vojnikom Sandom (Санде) iz sela Grizljevci, mobiliziranom u srpsku vojsku 1914., koji je od Kolevića (Колевић) ${ }^{117}$ kao austrougarski zarobljenik postao Kolef (Sande Kolef). Naime, na austrougarskoj dopisnici koju je poslao 1916. (kad je Makedonija pod bugarskom vlašću) postao je Kolef, ali je vlastitom rukom uz ime zemlje Bulgaria napisao Macedonia, a austorugarske su vlasti udarile i žig MAZEDONIEN. ${ }^{118}$ Vojnik Maнасuje, mobiliziran 1915. u srpsku vojsku, šalje pismo majci kao Велиновић ${ }^{119}$, a kao zarobljenik iz Galicije

\footnotetext{
111 Isto: 444, Д.К. 163. Fel. Post. Fel. je kratica зa Feldpostkarte (otisnuto cjelovito iznad adrese), dopisnica do zadnjeg mjesta s poštom.

112 Isto: 210

113 Isto: 212.

114 Isto: 211.

115 Turkmenski „gospodin“, posjednik, kulak, trgovac u srednjoj Aziji. U bugarskom jeziku se koristi kao titula za obraćanje sa značenjem „či čo” što je narodski ekvivalent za gospodin.

116 Isto: 286, 288.

117 Isto: 426, 427, Д.К. 94 i 60.

118 Isto: 428.

119 Isto: 467, Д.К. 55.
} 
majci piše dopisnicu ćirilicom kao Manasije Velinov (от Манасију Велинов). Prednju stranu s adresom vjerojatno je latinicom pisala druga osoba, pri čemu je ime pošiljatelja napisano Manasie Welinow, a ime i adresa primatelja, njegova brata, kao Ruse Welinowic, selo Kundino, Post. Kratovo, Neue Bulgaria. Iznad adrese dodano je in Mazedonien. ${ }^{120}$

Ovim originalnim dokumentima nije potreban poseban komentar. Ne samo vojnici, već $i$ austrougarske vlasti znali su prije stoljeća da Makedonija nije isto što i Bugarska. Na dopisnicama s imenom Bugarske dodavali su žig MAZEDONIEN. Nažalost, danas, poslije čitavog vijeka, mnogima to još nije jasno ili se prave da je tako.

Ime je zemlje očito bio razlog što ove dopisnice nisu isporučene unatoč tome što nisu sadržavale nikakve vojne podatke. Da ironija bude veća, upravo tijekom ovog, za balkanske narode tragičnog rata, a za sudbinu makedonskog naroda $\mathrm{s}$ najtragičnijim i trajnim posljedicama, najviše podataka ima o Makedoniji, ali ne iz znanstvenih pobuda, već zbog vojnih potreba. Njemačko ministarstvo vanjskih poslova formiralo je u proljeće 1917. pri generalštabu u Nišu „Makedonsko zemaljsko povjerenstvo“, koje čine arheolozi, geografi, geolozi, etnolozi itd., na čelu s Gustavom Weigandom. Tridesetorica su bila njemački znanstvenici, a šestorica iz regije. Zato su njemački autori napisali najviše radova o etnografiji, geologiji itd., osobito za područje današnje Republike Makedonije. ${ }^{121}$ Nakon njemačkog poraza u I. svjetskom ratu rezultate su objavljivali zasebno, a ne u enciklopediji o Makedoniji, kako je bilo planirano. ${ }^{122}$ Svestrano obrazovan profesor Leonard Schultze Jena (liječnik, geograf i zoolog) ${ }^{123}$ uspio se nakon završetka rata 1922. vratiti u Makedoniju (tada u Kraljevini SHS) te je prvi u zapadnoeuropskoj znanosti objavio mali fond od dvije stotine riječi makedonskog jezika ${ }^{124}$, kao dokaz, između ostalog, o samobitnosti Makedonaca. ${ }^{125}$

\footnotetext{
120 Isto: 468, Д.К. 119.

121 Najznačajnija su djela: WEIGAND 1924; MARGULIES 1926: 197-222.

122 О njemačkom znanstvenom zanimanju za Makedoniju vidi ОШЛИЦ 1985: 27-35, 49-53; ОШЛИЦ 1994: 31-41.

123 SCHULTZE JENA 1927; OSHLIES 2009: 71-80.

124 Da ironija bude veća, najstariji pisani slavenski jezik, materinski jezik Svete solunske braće Ćirila i Metoda, posljednji je standardizirani slavenski jezik te je proglašen službenim u NR Makedoniji 2. kolovoza 1944. u makedonskom manastiru Prohor Pčinjski, sada u Republici Srbiji.

125 TRAUTMANN 1948: 34.
} 


\section{Umjesto zaključka}

Ovi dokumenti pokazuju da su uvjeti za iskazivanje i održavanje nacionalnog identiteta na Balkanu tijekom stoljeća bili veoma teški. Naročito je to bio slučaj s Makedoncima zbog važnog strateškog položaja Moravsko-vardarske doline. Međutim i pored silnih pritisaka, kako od strane crkvenih tako i od strane državnih vlasti okupatora, Makedonci su ipak uspjeli sačuvati svoj identitet. Dokumenti, osobito dopisnice koje su slali zarobljeni makedonski vojnici u Prvom svjetskom ratu, očit su argument protiv tvrdnje da je makedonska nacija komunistička izmišljotina nastala poslije Drugog svjetskog rata, kada su Makedonci uspjeli stvoriti sadašnju državu, doduše tek na dijelu svoga povijesnog prostora, u tzv. vardarskom dijelu Makedonije, odnosno u današnjoj Republici Makedoniji, gdje mogu slobodno razvijati svoj nacionalni identitet. $\mathrm{U}$ ostalim dijelovima makedonskog povijesnog prostora koji danas pripadaju drugim suverenim državama (Grčka, Bugarska, Albanija i Kosovo) Makedonci ne mogu iskazivati, a kamoli razvijati svoj identitet, iako su lojalni građani država u kojima žive. Istinu za volji, u Albaniji je dozvoljena nastava na makedonskom beziku, ali samo u oblasti Donje Prespe, gdje je kompaktno makedonsko stanovnistvo, dok u oblastima uz granicu (Golo Brdo i Gora), gdje je stanovništvo miješano, iako prevladava makedonsko, identitet im nije priznat i nemaju se pravo obrazovati na vlastitom jeziku. Nasuprot tomu, sve manjine u suvremenoj makedonskoj državi su priznate, dok prava albanske manjine nadmašuju sve međunarodne norme.

Također, ne stoji teza da je je sazrijevanje makedonske nacije kasnilo, zbog kasnijeg stvaranje moderne države. Naime, u svijetu ima primjera očuvanja nacionalnog identiteta bez vlastite države, npr. Židova, Kurda, Gradišćanskih Hrvata koji žive izvan granica Hrvatske (Austrija, Mađarska i Slovačka) itd., što je mnogo teže bez državnih institucija i centralnog rukovodstva i tim prije potvrđuje postojanje nacionalnog identiteta, što je slučaj i s Makedoncima. Zato treba tragati za ovakvim dokumentima i detaljno ih obrađivati kako bi se rasvijetlio ne samo težak i dugotrajan proces razvitka nacionalnog identiteta Makedonaca, već i mnoga druga pitanja vezana za povijest makedonskog naroda.

S makedonskog prevela Bruna Kuntić-Makvić 


\section{Bibliografija}

АДАМОВСКИ, Горан. 2012. Српска прослава во Македонија. Утрински весник, бр. 4018, 29. Х. 2012., 3.

АПОСТОЛОВ Александар. 1993. „11-та македонска дивизија и нејзиното учество во Првата светска војна“. U Златна книга 100 години ВMPO, ur. A. Трајановски et alii. Скопје: Глас на ВМРО-ДПМНЕ.

АВИИ, Архив Војноисторијског института (АВИИ). Београд, фонд Први светски pam.

БАЛАН, Александар. 1904. Една македонска теория. Периодическо списание LXV: 818-819. = BALAN, Alexandar. 1978. A Macedonian theory. U About the Macedonian Language, 28-29. Skopje: Institut za makedonski jazik.

BARBUSSE, Henri. 1926. Les Bourreaux. Paris: Flammarion.

BARBUSSE, Henri. 1926a. La question macédonienne est-elle si complexe que cela. La Fédération Balkanique 51, 1. IX. 1926.

BARBUSSE, Henri. 1930. Un peuple asservi. Monde 108, 28. VI. 1930.

BART, Frederik. 1997. Etničke grupe i njihove granice. Beograd: Jugoslovensko udruženje za sociologiju.

BÉRARD, Victor. 1893. La Turquie et l'hellénisme contemporain. La Macédoine, Hellènes, Bulgares, Valaques, Albanais, Autrichiens, Serbes. La lutte des races. Paris: F. Alcan. BÉRARD, Victor. 1900. La Macédoine. Paris: A. Colin et cie.

BOUCHIE DE BELLE, Edmond. 1922. La Macédoine et les Macédoniens. Paris: Armand Colins.

BRAILSFORD, Henri. 1906. Macedonia, its Races and their Future. London: Methuen $\&$ Co.

БРЕЈЛСФОРД, Хенри. 2003. Македонија, нејзините народи и нејзината иднина. Скопје: Култура.

BOURLET, Michel, lieutenant. 2002. Les Slaves du Sud dans l'armée française pendant la Première Guerre mondiale. Revue Historique des armées 226 [La France et les Balkans]: 59-70.

BURNET, Emil. 1921. La tour blanche, armée d'Orient, 1916-1917. Paris: Ernest Flammarion.

Centenaire de la Première Guerre Mondiale, Le front d'Orient 1915-1918. 2014. Skopje: Ambassade de France en Macédoine.

ЦВЕТАНОСКИ, Виктор. 2009. Бугарските гробишта на патот на македонската иднина. Глобус 101, 24. III. 2009.

ЦВИЈИЋ, Јован. 1931. Балканско полуострво и Јужнословенске земље I-II. Београд: Државна штампарија.

ЦЕПЕНКОВ, Марко. 1972. Македонски народни умотворби, m. VI: народни приказни. Ur. К. Пенушлиски. Скопје: Македонска книга.

ЧЕПРЕГАНОВ, Тодор. 2010. Сведоштва за македонскиот идентитет (XVIII- XX век). Скопје: Инститиут з анационална историја. 
DANFORTH, Loring. 1995. The Macedonian conflict, ethnic nationalism in a transitional World. Princenton: Princenton University Press.

DECAMPES-LEQUINE, Sophie et alii (ur.). 2011. Au royaume d'Alexandre le Grand.

U La Macédoine antique (catalogue de l'exposition organisée au Louvre, 13. X. 2011

- 16. I. 2012.). Paris: Louvre and Somogy Editions d'art.

Elliniki foni, 8 VIII. 1959.

Foni tis Kastorias, 4. X. 1959.

ФРИДМАН, Виктор. 2003. Модерниот македонски стандарден јазик и неговата врска со модерниот идентитет. U Македонското прашање. Култура, историографија, политика, ur. Виктор Рудометоф, 241-288. Скопје: Евро Балкан пресс. = U The Macedonian Question: Culture, Historiography, Politics, ur. Victor Roudometof Boulder. CO: Columbia University Press, 2000.

ГАВРИЛОВИЋ, Андра. 1904. Пред четвртом књижевношћу. Бранково коло Х (17. IV. [29. V.] 1904.).

ГЕЛТОН, Фредерик. 2003. Македонското прашање и Франција, помеѓу регионалната историја и европската геополитика. U Прилози за Илинден IX, 29-40. Крушево: Десет дена крушевска република.

ГЕОРГИЕВСКИ, Борис. 2009. Војната за Македонија низ очите на Американците. Глобус 101 (24. III. 2009).

ХИТРОВА, Ирина. 1998. Век Екатерины II, Россия и Балканы. Москва: Наука.

ХРИСТОВ, Александар, Јован ДОНЕВ (ur.). 1994. Македонија во меѓународните договори. Скопје: Архив на Македонија - Матица Македонска.

HRON, Karl. 1890. Das Volkstum der Slaven Makedoniens. Vienna: F. Schalk.

KARAKASIDOU, Anastasia. 1997. Fields of Wheat, Hills of Blood. Chicago: University Chicago press. = КАРАКАСИДУ, Анастасија. 2002. Полиња жито, ридишта крв. Скопје: Магор

KATUNARIĆ, Vjeran. 2003. Sporna zajednica, novije teorije o naciji i nacionalizmu. Zagreb: Jesenski i Turk, Hrvatsko sociološko društvo.

KENNAN, George. 1993. The Other Balkans Wars: (1912 - 1913). Carnegie Endowment inquiry in Retrospect. Washington: Carnegie endowment for International Peace. = КЕНАН, Џорџ. 2000. Поранешните Балкански војни: (1912-1813) - извештај на Карнегиевата блканска комисија. Скопје: Култура.

ЛАЕ, Оливие. 2003. Источната француска армија при командата на сојузничките војски од пробивот на македонскиот фронт до капитулацијата на Бугарија. U Прилози за Илинден IX, 83-95. Крушево: Десет дена крушевска република.

LEBEDEV, Viktor. 1917. Souvenir d'un volontaire russe dans l'armée francais 1914 1916. Paris: Perrin.

LENINGTON, Hector. 1903. Turk as the critic of the Bible. The Sun. New York, 16th June 1903.

MARGULIES, Alfons. 1926. Historische Grundlagen der sudslavishen Sprachgliederung. Archiv fur slavische Philologie 40: 197-222.

МАТКОВСКИ, Александар. 1985. Македонскиот полк во Украина. Скопје: Мисла. 
МЛАДЕНОВ, М. Сл. 1985. За етнонима сърби (sirbi),„българи““ въ румънския език и румънската топонимия. Българска етнография X/3: 3-11.

МИНЧЕВ, Димитър. 1994. Участието на населението от Македония в Българската армия през Първата Световна война, 1914-1918. София: Мин. на отбраната. Нац. центьр по воен. История.

НАЈДОВСКА, Јасмина (ur.). 2008. Отпретани сведоштва, војнички писма од големата војна 1914 - 1918. Скопје: фондација Институт Отворено општество - Македонија.

НАСТЕВ, Божидар. 1965-1966. Н. Barbusse et la Macédoine (резиме). Годишен Зборник на Филозофскиот факултет (Скопје) 17-18: 205-234.

Н [ИКОЛИК'], С [узана]. 2012. Николиќ, обележувањето на Кумановската битка е порака за мирот. Дневник, бр. 5000, 29. Х. 2012, 3.

NOBIS, Charles. 1919. Lettre de Macedoine. Paris: Marcel Gilly.

ОШЛИЦ, Волф. 1984. Германските научници за македонските прашања. Спектар 4: 27-35.

ОШЛИЦ, Волф. 1985. Германските научници за македонските прашања. Спектар 5: 49-53.

ОШЛИЦ, Волф. 1994. Од историјата на германскот научно интересирање за Македонија. Историја 1-2: 31-41.

OSHLIES, Wolf. 2009. Leonard Schultze Jena as a German discoverer of the Macedonian Language (summary). U Откривањето и проучувањето на Македонија во европската наука до формирањето на македонските државни институции (Discovering and exploring Macedonia in European science until the establishment of Macedonian Institutions 2007), ur. Цветан Грозданов, 71-80. Skopje: MANU.

ПЕРИК', Миодраг. 1988. Историско-правните аспекти на односите помеѓу Српската православна ирква и Македонската православна ирква. Скопје: Мисла.

PETTIFER, James, Tom BUCHANAN (ur.). 2015. War in the Balkans: Conflict and Diplomacy Before World War I. New York-London: I. B. Tauris.

PROEVA, Nade. 2010. Savremeni makedonski mit kao odgovor na nacionalne mitove suseda: albanski panilirizam, bugarski pantrakizam i grčki panhelenizam. Zgodovinski časopis 64/1-2: 176-219.

ПРОЕВА, Наде. 2000. Предговор. U А. Делакулонш, Лулката на македонската државност. Ur. Наде Проева, 8-16. Скопје: Macedonia Prima.

ПРОЕВА, Наде. 2012. Националните митови во современа Европа и негирањето на македонскиот идентитет. Slavia Meridionalis 12: 107-158.

REISS, Rudolf. 1918. Sur la situation des Macédoniens et des musulmans dans les nouvelles provinces grecques. Paris: Plon, Nourrit.

РАТКОВИЋ, Борислав. 1975. Први балкански рат 1912-1913. Књ. 2. Београд: војно историјски институт.

100 години Прва светска војна, Фронтот и местата на сеќавање во Република Македонија. 1915-1918. 2014. Скопје: Ambassade de France en Macédoine.

SCHULTZE JENA, Leonard. 1927. Makedonien - Landschaft und Kulturbilder. Jena: Gustav Fischer. 
STEPPAN, HANS-LOTTAR. 2004. Der mazedonische Knoten, der Identität der Mazedonier dargstellt am Beispiel des Balkanbundes 1878 - 1814. Frankfurt/M: Peter Lang. = СТЕПАН, Ханс-Лотар. 2004. Македонскиот јазол, иентитетот на Македонците прикажан на примерот на Балканскот сојуз, 1878 - 1914. Скопје: Азбуки.

СТОЈАНОВ, Петар. 1969. Македонија во време на Балканските и Првата светска војна 1912-1918 година. Скопје: Институт за национална историја.

СТОЈАНОВСКИ, Александар. 2006. Македонија под турска власт. Скопје: Институт sа национална историја.

СТОЈЧЕВ, Ванче и СТОЈЧЕВ, Александар. 2013. Букурешкиот мировен договор и поделбата на Македонија во1913 година, Скопје: ИНИ

СТОЈЧЕВ, Александар. 2014. Македонскиот фронт и македонскиот национален идентитет во првата светска војна, зборник Македонија и Македонците во првата светска војна, научен собир на ИНИ и МАНУ, 11. 12. 2014. Битола, Скопје: МАНУ, во печат.

ШЕФЕР, Фабјен. 2014. 100 години прва светска војна, Фронтот и местата на сеќавање во Република Македонија. Скопје: Амбасада на Р. Франција.

SHAEFFER Fabien (réalisation). Centenaire de la Première Guerre Mondiale Front d'Orient 1914 - 1918. Skopje. http://wwwambafrance-mk.org/-Brochure-front-dOrient (pristup 28. 5. 2015).

Skrip, 9385, Athena, 8. VII. 1905.

TODOROVA, MARIA. 1997. Imagining the Balkans. Oxford: University Press.

ТРАЈКОВСКА, Мариела. 2012. Македонија нема повод за славење на балканските војни, Дневник, бр. 5000 (29. Х. 2012.): 3.

TRAUTMANN, Reinhold. 1948. Die slavishen Völker und ihre Sprachen. Leipzig: Otto Harrassowity.

VAN BOESCHOTEN, Riki. 1993. Ethnicity and the Cultural Division of Labour: the case of Macedonia conference. Paper presented at a conference on Ethnicity and Anthropology. Amsterdam.

VANKOVSKA, Biljana. 2015. History and Memories of the Balkan wars in the republic of Macedonia, debates over the past. U War in the Balkans: Conflict and Diplomacy Before World War I, ur. James Pettifer, Tom Buchanan, 92-111. N. York-London: I. B. Tauris.

WEIGAND, Gustav. 1942. Ethnographie von Makedonien. Leipzig: Friedrich Brandstetter.

ЗАРЕВСКА, Радмила. 2013. Портите на „Прохор Пчињски“ претешки и за Николиќ, Нова Македонија, бр. 22984 (23. IX. 2013.): 1-2.

ЗДРАВЕВА, Милка. 2005. Пресељеници из Македоније у руско царство средином 18 века. U Сеоба Срба у руско Царство половином 18 века. Нови Сад: Српско-украјинско друштво, Нови сад, Архив Војводине, Нови Сад Музеј града Новог Сада.

ЗДРАВКОВСКА, Жанета. 2013. Лисковски се борел за Турците, Србите и за Бугарите, на гробот му пишува дека служел за три војски. Дневник, бр. 5227 (27.-28. VII. 2013.): 3. 
ŽEFAROVIČ, Hristifor. 1741. Stematografija ili Izobraženije oružij iliričeskih (Fototiop Bec 1741). Prir. Toma Mesmer. Beograd: NIP Jugoslavija, EKO Bgd., 1990.

ЏИКОВ, Ставре. 2000. Свети Прохор Пчински. Скопје: Tajms Advertajzing.

ЧЕПРЕГАНОВ, Тодор. 2010. Сведочтва за македонскиот идентитет (XVIII-XX век). Скопје: Институт за национална историја.

\section{Macedonians and Macedonia in the First World War. A Contribution to the Research of Perception of National Identities}

The Balkan Wars represented a turning point in the history of the Balkan peoples, especially the Macedonian. The mass participation of the Macedonians under the flags of neighboring states and hoping to be liberated from the Ottoman authorities was fruitless because, with the consent of the Great powers, its ethnic territory was divided among the neighboring states, which was then cemented by the First World War. The paper is focused on the participation of the Macedonians in the First World War, which is slurred over by both the historians and the politicians who continue to follow the politics of that time, thus bolstering the denial of the Macedonian name, language, etc., by the neighbors who were not satisfied with the ,resolution“ of the Macedonian question. The historians, trapped within the national, or even more so the nationalistic historiographies that keep silent about the victims, military as well as civilian, justify this with the alleged national unawareness of the Macedonians, thus neglecting the existing testimonies about the national awareness. In doing so, they slur the propagandas of the neighbors who used their churches on the Macedonian territory to exert violent assimilation helped by the terror of the infiltrated armed squads. The paper is based on published archive resources, as well as on reports of foreign journalists and testimonies of participants in these wars, published after the end of the wars.

Keywords: Macedonia, Macedonian front, World War I, Balkan Wars, Bulgaria, Serbia, Greece, forced mobilization, volunteers, Ottoman authority

Ključne riječi: Makedonija, makedonska bojišnica, Prvi svjetski rat, Balkanski ratovi, Bugarska, Srbija, Grčka, prisilna mobilizacija, dobrovoljci, osmanska vlast

Nade Proeva

Institut za istorija, Filozofski fakultet Univerzitet sv. Kiril i Metodij MA-1000 Skopje, Bulevar Goce Delčev 9a 


\section{FILOZOFSKI FAKULTET SVEUČILIŠTA U ZAGREBU \\ ZAVOD ZA HRVATSKU POVIJEST \\ INSTITUTE OF CROATIAN HISTORY \\ INSTITUT FÜR KROATISCHE GESCHICHTE}
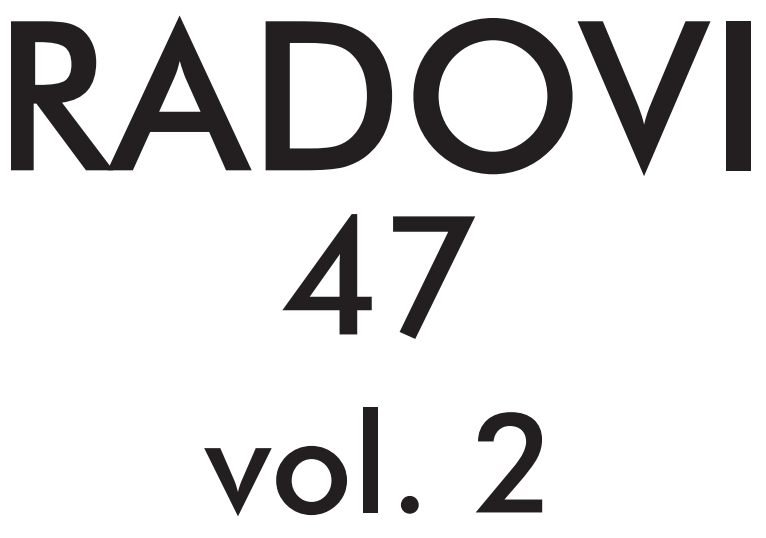

ZAVOD ZA HRVATSKU POVIJEST

FILOZOFSKOGA FAKULTETA SVEUČILIŠTA U ZAGREBU

FF press

ZAGREB 2015. 


\title{
RADOVI ZAVODA ZA HRVATSKU POVIJEST FILOZOFSKOGA FAKULTETA SVEUČILIŠTA U ZAGREBU
}

\author{
Knjiga 47, vol. 2
}

\author{
Izdavač / Publisher \\ Zavod za hrvatsku povijest \\ Filozofskoga fakulteta Sveučilišta u Zagrebu \\ FF-press \\ Za izdavača / For Publisher \\ Vlatko Previšić \\ Glavni urednik / Editor-in-Chief \\ Hrvoje Gračanin \\ Izvršna urednica / Executive Editor \\ Inga Vilogorac Brčić \\ Uredništvo / Editorial Board
}

Bruna Kuntić-Makvić (stara povijest/ancient history), Zrinka Nikolić Jakus (srednji vijek/ medieval history), Hrvoje Petrić (rani novi vijek/early modern history), Željko Holjevac (moderna povijest/modern history), Tvrtko Jakovina (suvremena povijest/contemporary history),

Silvija Pisk (mikrohistorija i zavičajna povijest/microhistory and local history),

Zrinka Blažević (teorija i metodologija povijesti/theory and methodology of history)

Međunarodno uredničko vijeće / International Editorial Council

Denis Alimov (Sankt Peterburg), Živko Andrijašević (Nikšić), Csaba Békés (Budapest), Rajko Bratož (Ljubljana), Snježana Buzov (Columbus, Ohio), Svetlozar Eldarov (Sofija), Toni Filiposki (Skopje), Aleksandar Fotić (Beograd), Vladan Gavrilović (Novi Sad), Alojz Ivanišević (Wien),

Egidio Ivetić (Padova), Husnija Kamberović (Sarajevo), Karl Kaser (Graz),

Irina Ognyanova (Sofija), Géza Pálffy (Budapest), Ioan-Aurel Pop (Cluj),

Nade Proeva (Skopje), Alexios Savvides (Kalamata), Vlada Stanković (Beograd), Ludwig Steindorff (Kiel), Peter Štih (Ljubljana)

Izvršna urednica za tuzemnu i inozemnu razmjenu / Executive Editor for Publications Exchange Kristina Milković

Tajnik uredništva / Editorial Board Assistant
Dejan Zadro

Adresa uredništva/Editorial Board address

Zavod za hrvatsku povijest, Filozofski fakultet Zagreb, Ivana Lučića 3, HR-10 000, Zagreb

Tel. ++385 (0)1 6120 150, 6120 158, faks ++385 (0)1 6156879

Časopis izlazi jedanput godišnje / The Journal is published once a year

Časopis je u digitalnom obliku dostupan na / The Journal in digital form is accessible at Portal znanstvenih časopisa Republike Hrvatske „Hrčak“ http://hrcak.srce.hr/radovi-zhp

Financijska potpora za tisak časopisa / The Journal is published with the support by

Ministarstvo znanosti, obrazovanja i športa Republike Hrvatske

Časopis je indeksiran u sljedećim bazama / The Journal is indexed in the following databases:

Directory of Open Access Journals, EBSCO, SCOPUS, ERIH PLUS 
Naslovna stranica

Iva Mandić

Grafičko oblikovanje i računalni slog

Marko Maraković

Lektura

Samanta Paronić

Tisak

Web2tisak, Zagreb

Naklada

250 primjeraka

Časopis je u digitalnom obliku dostupan na Portalu znanstvenih časopisa Republike Hrvatske ,Hrčak“ http://hrcak.srce.hr/radovi-zhp

The Journal is accessible in digital form at the Hrcak - Portal of scientific journals of Croatia http://hrcak.srce.hr/radovi-zhp 


\section{RADOVI 47}

\section{vol. 2}

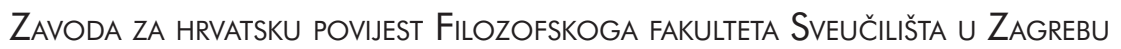

